\title{
Some Recent Advances in the Design and Use of Molecular Balances for the Experimental Quantification of Intramolecular Noncovalent Interactions of $\pi$ Systems
}

\author{
Abil E. Aliev and William B. Motherwell \\ Department of Chemistry, University College London, 20 Gordon Street, London WC1H OAJ, UK.
}

\section{Introduction}

The essential role played by noncovalent interactions in controlling three-dimensional molecular recognition in virtually all chemical reactions and biological processes, as well as in supramolecular chemistry, host-guest complexation and crystal engineering is now firmly established. ${ }^{[1,2]}$ To a certain degree, life itself can now be spoken of as a manifestation of multiple noncovalent interactions, acting in a combined or cooperative fashion. ${ }^{[3]}$ Whilst strong noncovalent interactions, such as hydrogen bonds, have been scrutinised extensively, ${ }^{[1,2]}$ it has become increasingly clear over the last three decades that noncovalent interactions of aromatic rings and double bonds are also indispensable. ${ }^{[4-9]}$ Approaches based upon structural database mining, ${ }^{[11]}$ and early experimental gas phase studies ${ }^{[12]}$ have all corroborated the involvement of $\pi$ systems in noncovalent interactions. Thus, detailed studies of a diverse range of noncovalent $\pi$-interactions have been undertaken, which involved such pairs as Aryl $\cdots$ Aryl, ${ }^{[6]}$ Cation $\cdots \pi{ }^{[7]}$ Anion $\cdots \pi,{ }^{[8]}$ and $\mathrm{CH} \cdots \pi,{ }^{[9]}$ as well as the investigation of the critical role played in all chemical and biochemical reactions by solvation. ${ }^{[10]}$ All of these phenomena are now regarded as a sine qua non for the ultimate objective of rational design.

In view of their ubiquitous significance, an experimental quantitative assessment of the strength of a noncovalent interaction is most desirable. The latter has proven to be rather difficult for the noncovalent interactions of $\pi$ systems since they are relatively weak. Thus, various small molecules have been designed for the evaluation of their strength.

Since many complex biological systems involve multiple noncovalent interactions, it is, therefore, essential to isolate a particular noncovalent interaction of interest. This is most readily achieved through the synthesis of a molecule with limited degrees of conformational freedom whose geometry is such that the desired noncovalent interaction to be observed and measured is now intramolecular. In the ideal world, in order to limit possible competing contributions from steric effects, solvation, and other secondary interactions, such a molecule 
must be carefully designed and should also possess a high degree of symmetry. Compared to other techniques, NMR spectroscopy has proven to be the most useful tool for extraction of free energy differences by measurement of the relative populations of the two equilibrating conformers, and hence this class of molecules can function as molecular balances. Following on from the pioneering studies by Ōki and coworkers in 1974 using the triptycene framework, ${ }^{[13]}$ the introduction of the designed "molecular torsion balance" by Wilcox ${ }^{[14]}$ provides a typical illustration of how such weak interactions can be quantified and further reports $^{[15 \mathrm{a}-\mathrm{c}]}$ using this balance confirm the power of this modus operandi (vide infra).

The use of a wide variety of molecular balances to quantify noncovalent interactions has been analysed and summarised in a very insightful review by Cockroft. ${ }^{[16 a]}$ In a recent article, Strauss and Wegner have considered geometrically well-defined molecular model systems for systematic examination and quantification of London dispersion interactions. ${ }^{[16 b]}$ An interactive application of complimentary experimental and computational techniques to studies of Aryl $\cdots$ Aryl $\pi$-stackings was also reviewed by Shimizu et al. in 2017. ${ }^{[16 c]}$

In the following report we wish to present some examples of recent progress in this field using more established frameworks, but also to emphasise the fact that whilst the vast majority of balances studied to date have relied on slow rotation around a single sigma bond, alternative designs are also possible. Herein, we consider relatively simple synthetic molecular balances which are used to study intramolecular noncovalent interactions, while those relying on intermolecular interactions (e.g. see reports by Sherburn et al. ${ }^{[17 \mathrm{a}]}$, Shimizu et $a .^{[17 \mathrm{~b}]}$ and Schreiner et $a .^{[17 \mathrm{c}]}$ ) are beyond the scope of this review. As indicated in the title, we mainly focus on noncovalent interactions of $\pi$ systems in this article, such as those of aromatic and heteroaromatic rings and double bonds. Analysis of current theoretical and computational studies are not included in this review unless relevant to the discussion of the particular molecular balance considered. The latter area has already produced a vast pool of publications from several leading research groups, ${ }^{[18]}$ who are well-placed to review the rapidly expanding field of computational studies of noncovalent interactions.

\section{Aryl ester balances of Wilcox}

In their 1994 paper, ${ }^{[14 a]}$ Wilcox et al. suggested to use conformational variations as a sensitive probe of weak interactions. They showed that a molecule exchanging between two conformers, 
would permit to experimentally evaluate Aryl $\cdots$ Aryl interaction energies, provided only one of the conformers exhibits an Aryl $\cdots$ Aryl interaction of interest. As stated then, ${ }^{[14 a]}$ such a molecule "would act as a simple torsion balance" and "deviations from the 1:1 ratio of states would reveal intramolecular forces".
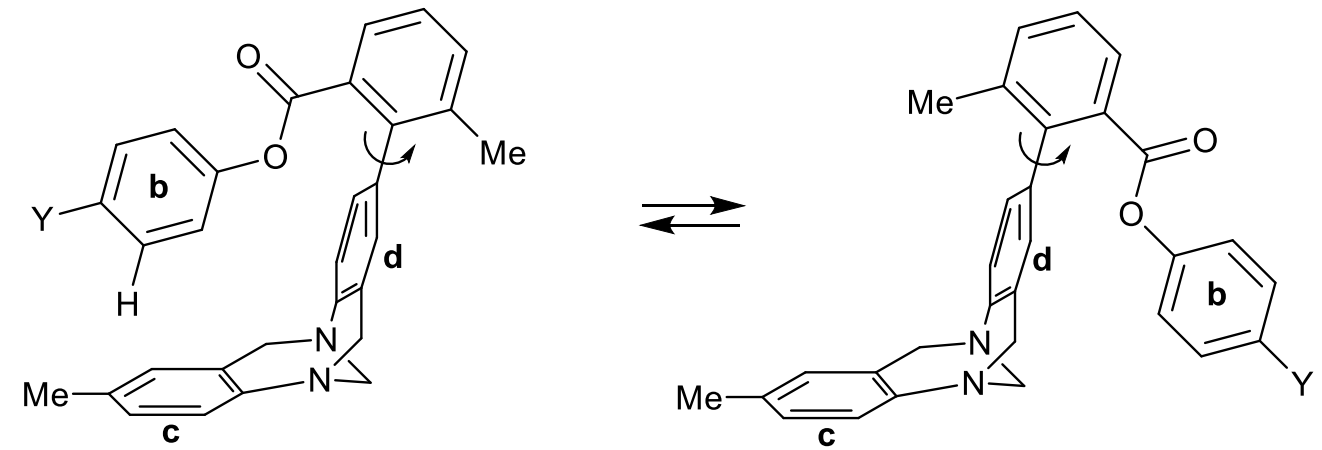

Figure 1. A two-site conformational exchange for the Wilcox aryl ester balance $\mathbf{1}(\mathrm{Y}=\mathrm{H})$. The rotation about the Aryl-Aryl bond (indicated with curved arrows) is slow in the NMR timescale at $298 \mathrm{~K}$, hence two distinct sets of peaks are observed in ${ }^{1} \mathrm{H}$ NMR spectra.

Various esters were considered. It was assumed that ring $\mathbf{b}$ adopts a tilted-T orientation relative to ring $\mathbf{c}$ in the folded conformer (Figure 1, left side), whilst in the unfolded conformer (Figure 1, right side), the spatial proximity of these two rings is lost. Crystal structures showed rings $\mathbf{b}$ and $\mathbf{c}$ in an approximately tilted-T orientation. From NMR measurements of phenyl ester $\mathbf{1}$ (with $\mathrm{Y}=\mathrm{H}$ ) at $298 \mathrm{~K}$, the folded state is preferred with a ratio of $3: 2$ or $\Delta G^{\mathrm{o}}$ fold $=-1.00 \mathrm{~kJ} \mathrm{~mol}^{-}$ 1. The observed ratio of conformational states was unchanged in $\mathrm{CDCl}_{3}, \mathrm{CD}_{3} \mathrm{NO}_{2}, \mathrm{DMSO}-d_{6}$, $\mathrm{C}_{6} \mathrm{D}_{6}$ and $\mathrm{CCl}_{4}$. Electron-withdrawing substituents $p$-cyano and $p$-nitro (in position $\mathrm{Y}$ ) showed $\Delta G_{\text {fold }}^{\mathrm{o}}=-2.72 \mathrm{~kJ} \mathrm{~mol}^{-1}$ in $\mathrm{CDCl}_{3}$. In a further report, Wilcox et al. considered various substitution patterns in rings $\mathbf{b}$ and $\mathbf{c}$, as well as a full replacement of ring $\mathbf{b}$ with an aliphatic group for the investigation of $\mathrm{CH} \cdots \pi$ interactions. ${ }^{[14 \mathrm{~b}]}$ The Wilcox balance was also used by Diederich et $a l^{[15 a]}$ to study a weak attraction between a trifluoromethyl group and the face of an amide group (Figure 2). Subsequently, Cockroft and Hunter ${ }^{[15 b, 15 c]}$ used the Wilcox balance for the quantification of pairwise interactions in solution. In similar fashion, Alkyl $\cdots$ Alkyl interactions and Alkyl...Perfluoroalkyl interactions have been studied by the Cockroft group ${ }^{[10 a]}$ through strategic incorporation of these units. One of the major findings by Cockroft et al. ${ }^{[10 \mathrm{a}]}$ was that "theoretical models that implicate important roles for dispersion forces in molecular recognition events should be interpreted with caution in solvent-accessible systems". In particular, it was shown that on going from gas phase to solution state the folding free energy 
of the Wilcox balance significantly decreases. ${ }^{[10 a]}$ The latter was further confirmed by Heßelmann and Ferraro using various computational techniques. ${ }^{[10 \mathrm{e}]}$

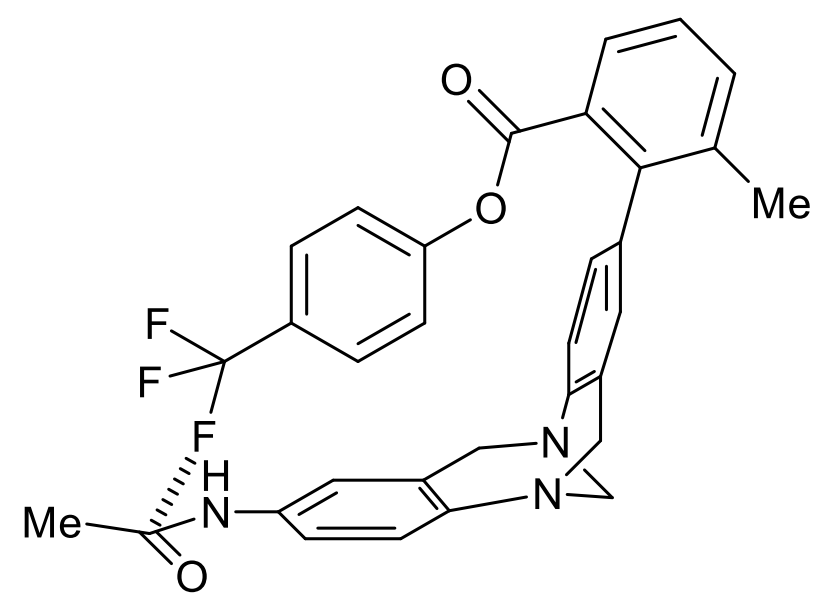

Figure 2. The Wilcox balance 2 used by Diederich et al. ${ }^{[15 a]}$ to study a weak F... Amide attraction.

Further useful modifications of the framework of the Wilcox balance have been reported by Bhayana and coworkers, ${ }^{[15 d, e]}$ where an additional methylene group is added to the $\mathrm{N}-\mathrm{CH}_{2}-\mathrm{N}$ bridgehead ${ }^{[15 \mathrm{~d}]}$ or the phenyl ester is replaced by a naphthyl alkyl ether. ${ }^{[15 \mathrm{e}]}$ In a recent report, they used a balance, in which the phenyl ester is replaced with a nitroalkene substituted naphthalene ring. ${ }^{[15 f]}$ This modification allowed them to study intramolecular Aryl $\cdots \mathrm{NO}_{2}$ interactions, the strength of which is estimated to be less than $4.18 \mathrm{~kJ} \mathrm{~mol}^{-1}$ in different solvents. ${ }^{[15 f]}$

Although the Wilcox balances have been widely used, their use is based on the assumption that the approximately tilted- $T$ arrangement of rings $\mathbf{b}$ and $\mathbf{c}$ observed in the crystalline phase is also retained in various solutions considered in NMR measurements. However, the preference of the approximately tilted-T arrangement of two rings in the crystalline phase may be the consequence of the crystal packing effects (i.e. driven by intermolecular interactions between two or more molecules placed in close proximity of each other) rather than the conformational preference of the molecular geometry itself. In fact, the aromatic ring $\mathbf{b}$ with no $o, o^{\prime}-$ disubstitution is free to rotate about the $\mathrm{C}-\mathrm{O}$ bond and may potentially adopt many different conformations.

Using various examples, it has been shown previously that the preferred molecular geometry of an isolated molecule is often modified in the solid state by intermolecular interactions 
originating from dense molecular packing. ${ }^{[10 \mathrm{c}]}$ Thus, structures determined by diffraction techniques in the solid state may differ significantly from those determined by NMR in solution. It was found that compared to the solid-state molecular structures, the predicted geometries for isolated single molecules in solution or gas phases by computational techniques often agree better with the measured NMR parameters in solution. ${ }^{[10 \mathrm{c}]}$ Our relaxed grid searches using molecular mechanics calculations ${ }^{[19 a, b]}$ of the Wilcox balance 1 (Figure 1), followed by geometry optimisations of the selected lowest energy conformers at the density functional theory (DFT) level ${ }^{[19 c, d]}$ showed that the single molecule does not adopt a tilted-T orientation of rings $\mathbf{b}$ and $\mathbf{c}$ (Figure 3). These calculations revealed that the Wilcox balance could potentially show other noncovalent interactions not discussed previously. From the geometries shown in Figure 3, the closest $\mathrm{H}_{\text {arom }} \cdots \mathrm{C}_{\text {arom }}$ distance between aromatic hydrogen and carbon atoms is $3.48 \AA$ for rings $\mathbf{b}$ and $\mathbf{c}$. While the $\mathrm{H}_{\text {arom }} \cdots \mathrm{C}_{\text {arom }}$ interaction for rings $\mathbf{b}$ and $\mathbf{c}$ was the main focus of the previous studies, the closest $\mathrm{H}_{\text {arom }} \cdots \mathrm{C}_{\text {arom }}$ distance is $2.96 \AA$ for rings $\mathbf{b}$ and d. The contribution from the interaction between the methyl protons and aromatic ring $\mathbf{b}$ with the closest $\mathrm{H}_{\text {aliph }} \cdots \mathrm{C}_{\text {arom }}$ distance of $3.04 \AA$ is also expected to be significant in the folded conformer (Figure 3). Most importantly, aliphatic protons of the $\mathrm{NCH}_{2}$ groups are in close proximity of the ring $\mathbf{b}$ in the unfolded conformer with the closest $\mathrm{H}_{\text {aliph }} \cdots \mathrm{C}_{\text {arom }}$ distances of 3.03 and $3.14 \AA$ A. Thus, the Wilcox balance essentially compares the strengths of the multiple

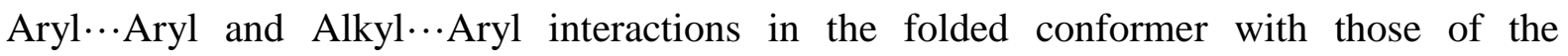
Alkyl $\cdots$ Aryl interactions in the unfolded conformer. In light of these considerations, it would be necessary to additionally investigate the preferred geometry of the Wilcox balance in the gas and solution states using advanced computational and experimental techniques. One of our reviewers has suggested that the very highly polar bonds in balances such as those based on the Wilcox framework can display addition polar effects which are not accounted for, especially in solution. Alternatively, simpler balances could be chosen which are restricted to two possible conformers only in order to exclude ambiguities associated with the variety of possible conformations in open chain systems with ordinary bonds. 


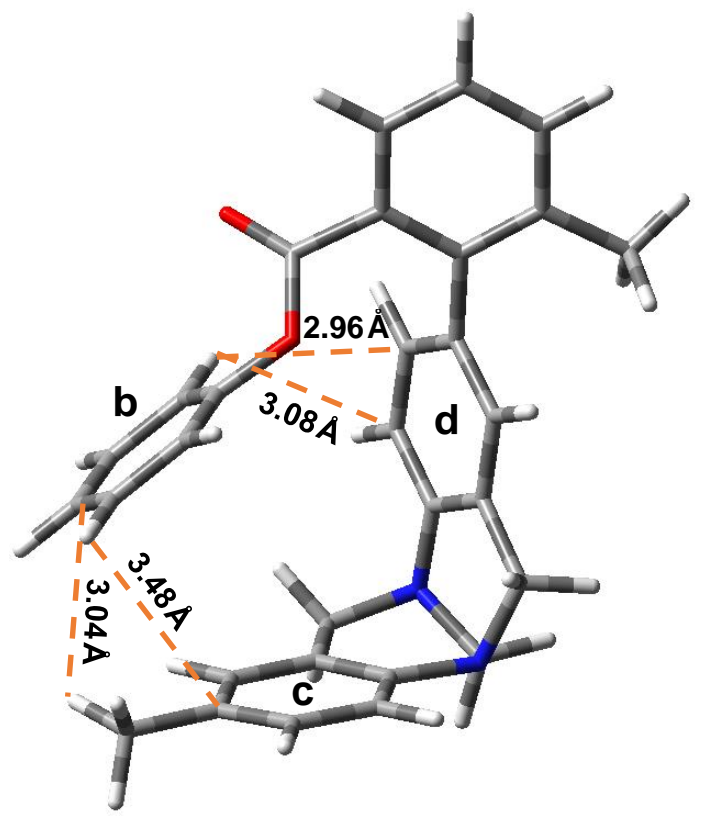

folded

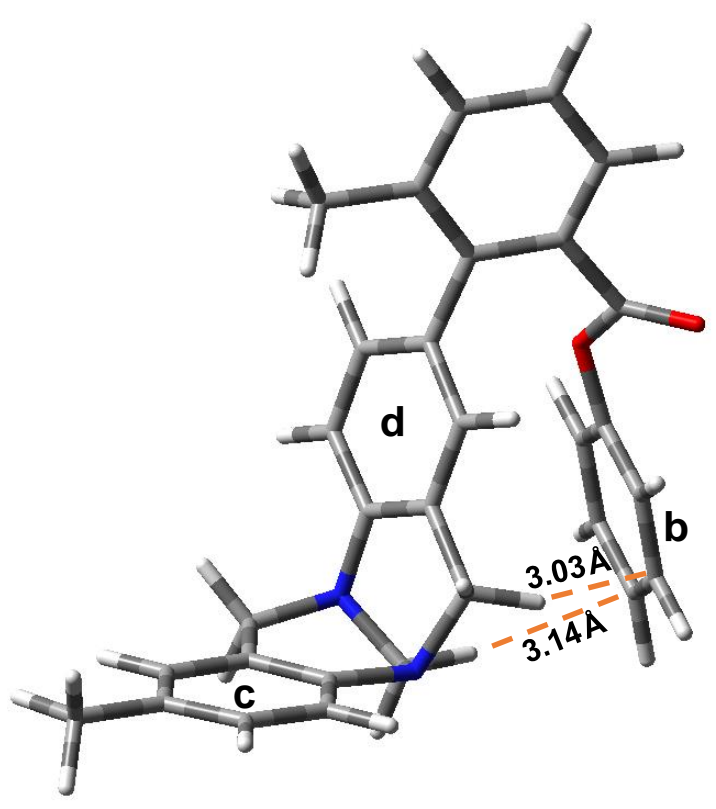

unfolded

Figure 3. Optimised geometries of the Wilcox balance 1 in the folded (left) and unfolded (right) conformations using DFT M062X/def2-TZVP ${ }^{[19 c, d]}$ calculations. The closest distances between hydrogen atoms and aromatic carbon atoms are also shown. Chloroform solvent effects were introduced via self-consistent reaction field theory calculations using the IEFPCM method. ${ }^{[19 \mathrm{e}]}$ Frequency calculations confirmed that the optimized geometries correspond to true minima. The predicted relative stability of the unfolded conformer relative to that of the folded conformer is $3.47 \mathrm{~kJ} \mathrm{~mol}^{-1}$, corresponding to the predicted populations of $80 \%$ and $20 \%$ for folded and unfolded conformers in the chloroform solution.

\section{Biaryl balances of Cozzi and Siegel}

Using doubly-substituted 1,8-diarylnaphthalenes (Figure 4a), Cozzi and Siegel have studied the role of Polar $\cdots \pi$ and charge transfer forces in stabilising a stacked orientation of two phenyl groups. $^{[6 \mathrm{a}, 20]}$ 


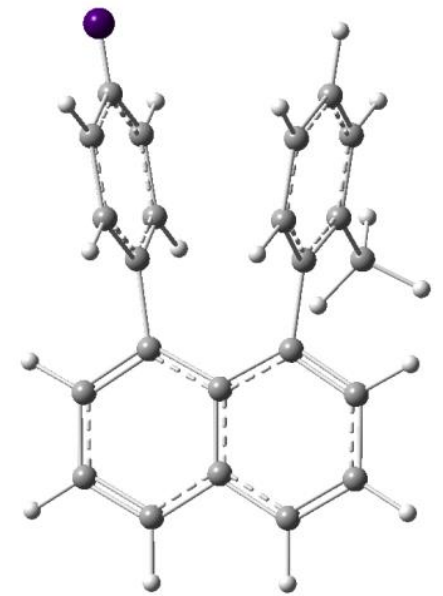

(a)

3

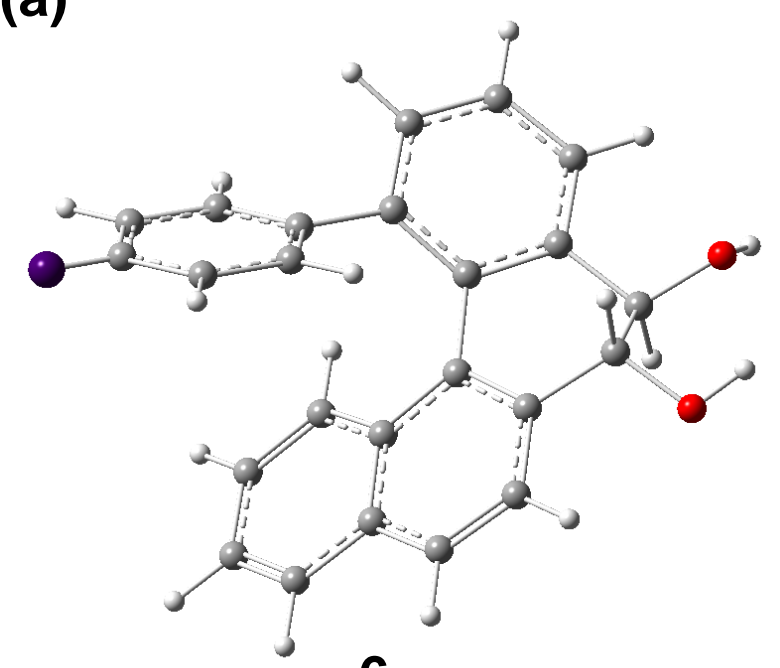

(b)

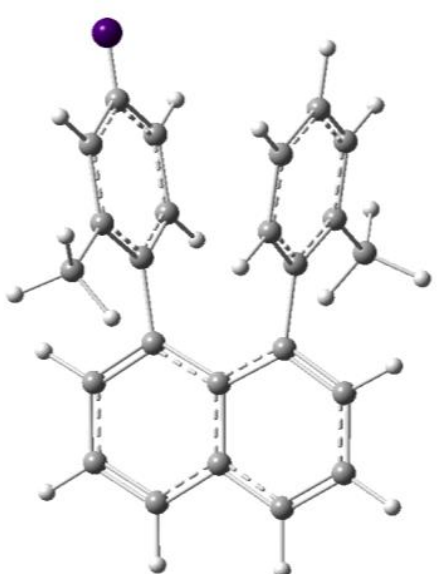

4

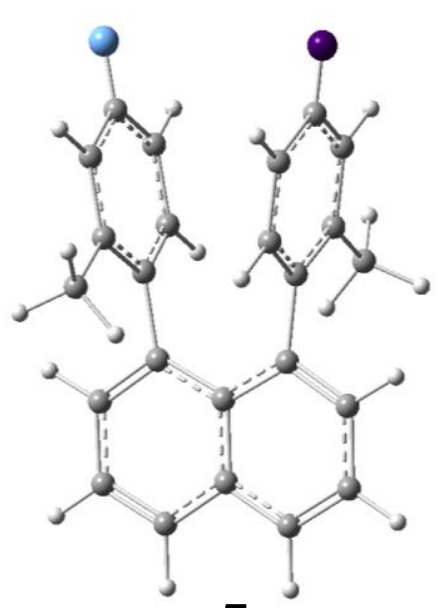

5

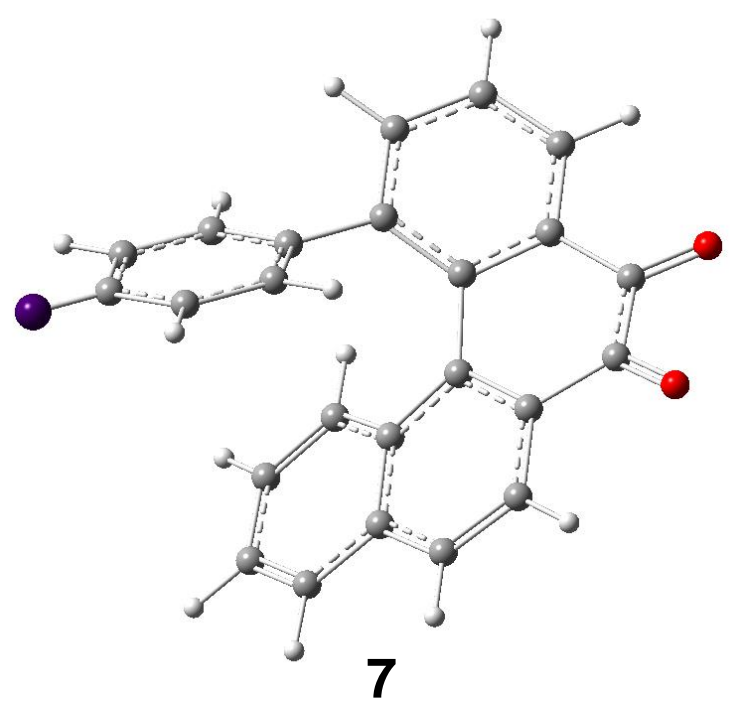

Figure 4. Aromatic molecular balances used by Cozzi and Siegel: ${ }^{[6 a, 20]}$ a) doubly substituted 1,8-diarylnaphthalenes ${ }^{[20 a, b]}$ 3-5 and b) conformationally restricted polycyclic compounds 6 and 7. ${ }^{[20 \mathrm{c}]}$ Atoms $\mathrm{H}, \mathrm{C}$ and $\mathrm{O}$ are shown in white, grey and red, respectively. Positions of varied substituents $\mathrm{X}$ and $\mathrm{Y}$ are shown in purple and blue, respectively. Typical $\mathrm{X}$ and $\mathrm{Y}$ substituents considered were $\mathrm{H}, \mathrm{Me}, \mathrm{F}, \mathrm{OMe}, \mathrm{COOMe}$ and $\mathrm{NO}_{2}$. Optimised geometries $(\mathrm{X}=\mathrm{Y}=\mathrm{H})$ using the MMX force field ${ }^{[19 a, b]}$ for a single molecule in vacuo are shown.

Experimentally, the variations in the barrier of epimerisation were measured using NMR. Based on the obtained results, it was predicted that "the face-to-face complexation of a neutral aromatic guest with a neutral aromatic host should show increased stability when both partners are electron-poor". The results established the supremacy of Polar $\cdots \pi$ forces over charge transfer interactions in stabilising the stacked arrangement of two phenyl rings. ${ }^{[20 a]}$ 
1,8-Disubstituted naphthalene models were also used by Zoltewicz et al. ${ }^{[21]}$ to measure the ratio of anti and syn atropisomers by NMR and monitor the dependence of this ratio on Cation...Arene and $\mathrm{CH} \cdots$ Arene interactions. The results supported the conclusion that the electrostatic repulsion is likely to favour the anti atropisomer in the majority of cases considered.

Two sets of polycyclic molecular balances (Figure 4b) were also used by Cozzi and Siegel to study noncovalent interactions in parallel-displaced geometries of aromatic rings. ${ }^{[20 \mathrm{c}]} \mathrm{By}$ varying substituent $\mathrm{X}$ and measuring the free energy of activation $\left(\Delta G^{\ddagger}\right)$ for the rotation around the Aryl-Aryl bond in the para position relative to $\mathrm{X}$, they found that the $\Delta G^{\neq}$values decrease on going from electron-withdrawing to electron-donating substituents. The authors concluded that the Arene...Arene interactions in parallel-displaced geometries of aromatic rings are governed by electrostatic forces, ${ }^{[20 \mathrm{c}]}$ as in the case of the stacked sandwich (parallel-stacked) and T-shaped (edge-to-face) geometries.

\section{N-Arylimide balances}

It is surprising to learn that the very first examples of NMR measurements of the restricted Naryl bond rotation in N-ortho-aryl substituted succinamides (Figure 5) ${ }^{[22]}$ date back over 40 years to a seminal paper by Verma and Singh. ${ }^{[23]}$ Due to the restrictions imposed by the rigid molecular frame and the proximity of the two carbonyl groups, the $\mathrm{N}$-aryl group is approximately perpendicular to the aromatic ring of the 9,10-dihydroanthracene base, adopting an edge-to-face alignment. Thus, the $\mathrm{R}$ substituent of the $\mathrm{N}$-aryl fragment $(\mathrm{R}=\mathrm{Me}$ in Figure 5 ) is placed either near (Figure 5, left side) or away (Figure 5, right side) from the aromatic ring of the 9,10-dihydroanthracene base. It is likely that the R-endo (or folded) conformer is destabilised by steric and electronic repulsions, and hence the strength of any favourable interaction of an $\mathrm{R}$ substituent with the $\pi$-system must be weighed against these repulsions. In spite of this inherent design limitation, it is possible to attenuate the electronic character of the $\mathrm{N}$-aryl group through incorporation of an $\mathrm{X}$ group, and, as exemplified in a beautiful study by Cozzi and coworkers ${ }^{[22]}$ to probe the $\mathrm{CH} \cdots \pi$ interaction of a methyl substituent $\mathrm{R}$. We note that although this molecular balance is structurally similar to that by Wilcox et al. ${ }^{[14]}$ the principal advantage of the balance based on the $\mathrm{N}$-arylamide unit is that it allows monitoring of the two distinct folded and unfolded conformations about an imide bond by direct integration of ${ }^{1} \mathrm{H}$ NMR spectra. 


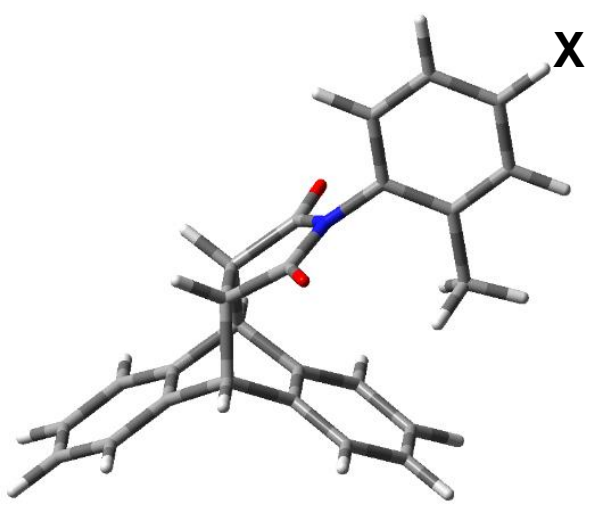

endo (folded)

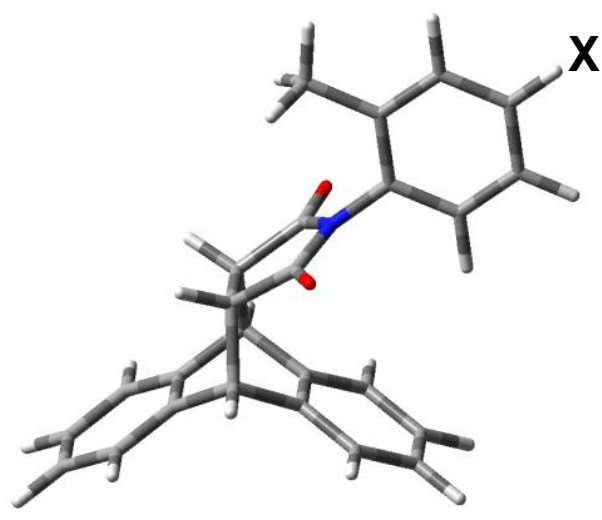

exo (unfolded)

Figure 5. Structures of the R-endo and R-exo conformers of succinamides $8(X=H)$ and $9(X$ $=\mathrm{NO}_{2}$ ). The example where $\mathrm{R}=\mathrm{Me}$ is shown. For $\mathbf{8}$ and $\mathbf{9}$, the endo : exo ratio of conformers were 46:54 and 70:30, respectively. Optimised geometries $(\mathrm{X}=\mathrm{H})$ using the MMX force field ${ }^{[19 a, b]}$ for a single molecule in vacuo are shown.

Balances similar to that shown in Figure 5 were also extensively explored by Emenike et al. ${ }^{\text {[24] }}$ to study $\mathrm{CH} \cdots \pi$ interactions, including cationic $\mathrm{N}^{+} \mathrm{CH}_{3} \cdots \pi$ contacts.

Within the last decade, the $\mathrm{N}$-aryl succinimide motif has effectively been claimed by the Shimizu group and the basic framework has been cleverly modified and extended to encompass an array of planar polycyclic aromatic units. ${ }^{[25 a-j]}$ Thus, in 2008, as illustrated in Figure 6, they considered molecular balances in which face-to-face Aryl ...Aryl alignments are likely to be observed. $^{[25 \mathrm{e}]}$ They first used this molecular balance to measure face-to-face Aryl $\cdots$ Aryl interactions (Figure 6). The reported values of the free energy difference ( $\Delta G^{\mathrm{o}}$, at $298 \mathrm{~K}$ in $\mathrm{CDCl}_{3}$ ) for the Aryl $\cdots$ Aryl interaction were $-4.23 \mathrm{~kJ} \mathrm{~mol}^{-1}$ in $\mathbf{1 0}$ and $-3.51 \mathrm{~kJ} \mathrm{~mol}^{-1}$ in $\mathbf{1 1}$, which were in agreement with those reported by Cozzi et al. ${ }^{[6 \mathrm{a}]}$ and Wilcox et al. ${ }^{[14 \mathrm{~b}]}$ The solvent dependence studies revealed that more polar solvents lead to greater degrees of folding in $\mathbf{1 0}$ and $\mathbf{1 1 .}$ 

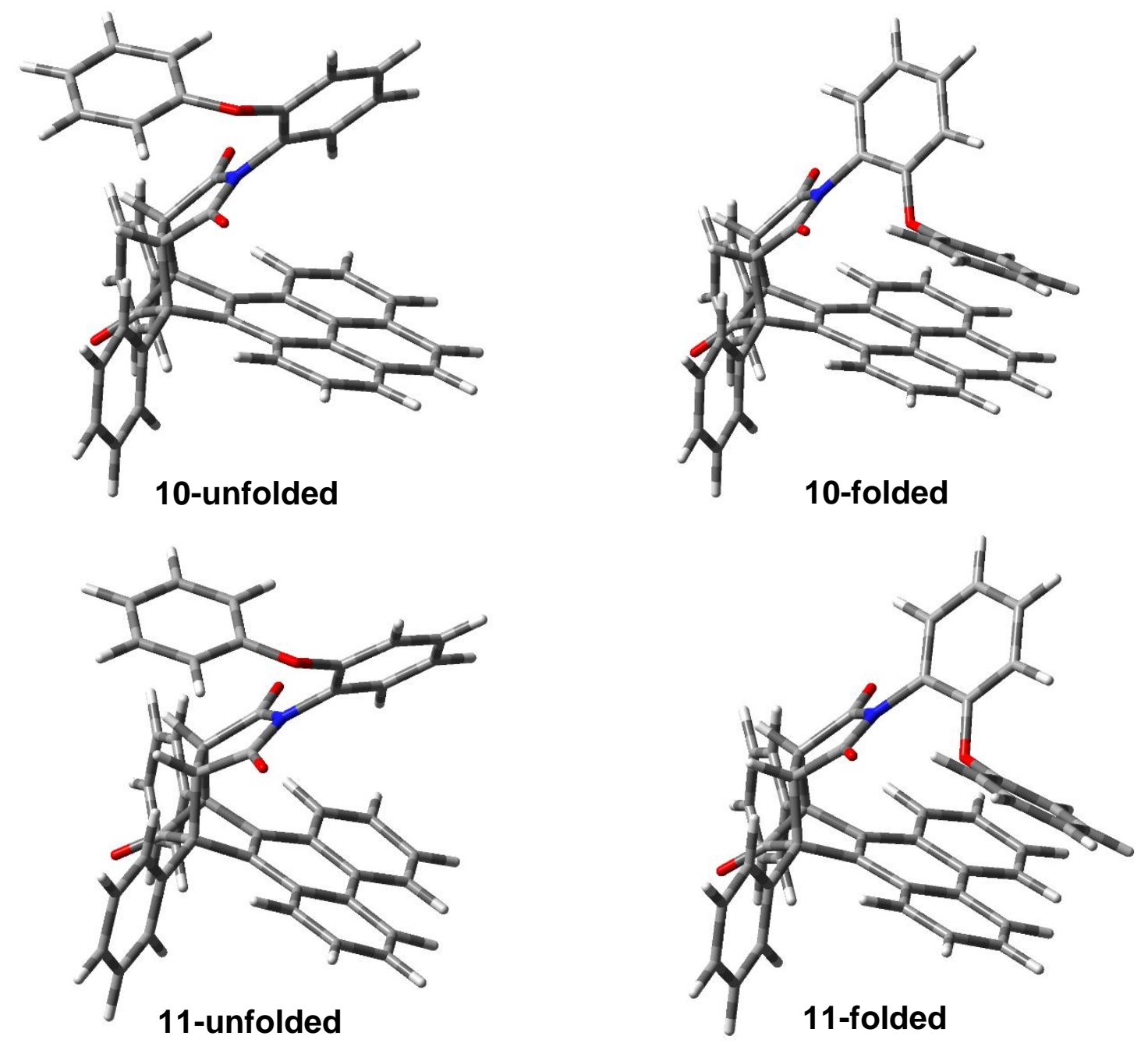

Figure 6. Conformer geometries of the Shimizu molecular balances 10 and 11. Optimised geometries using the MMX force field ${ }^{[19 a, b]}$ for a single molecule in vacuo are shown.

Shimizu et al. also studied $\mathrm{CH} \cdots \pi$ interactions in Alkyl $\cdots$ Aryl pairs (Figure 7 ), ${ }^{[25 c]}$ the stabilising effect of which was estimated to be $-3.97 \mathrm{~kJ} \mathrm{~mol}^{-1}$ for the $\mathrm{OCH}_{3} \cdots$ Phenanthrene pair (Figure 7) and $-4.35 \mathrm{~kJ} \mathrm{~mol}^{-1}$ for the $\mathrm{OC}_{2} \mathrm{H}_{5} \cdots$ Phenanthrene pair at $298 \mathrm{~K}$ in $\mathrm{CDCl}_{3}$. For the alkoxy groups of varying lengths and widths $\left[\mathrm{OCH}_{3}, \mathrm{OC}_{2} \mathrm{H}_{5}, \mathrm{OCH}\left(\mathrm{CH}_{3}\right)_{2}, \mathrm{O}\left(\mathrm{CH}_{2}\right)_{3} \mathrm{CH}_{3}\right.$ and $\left.\mathrm{OC}_{6} \mathrm{H}_{11}\right]$, it was found that bulky alkoxy groups appear to decrease the strength of the attractive $\mathrm{CH} \cdots \pi$ forces. ${ }^{[25 \mathrm{c}]}$ Contrary to previously obtained results, Shimizu et al. concluded that in their case the Lone Pair (LP) $\cdots \pi$ interaction was repulsive in nature. Further X-ray and NMR studies of $\mathrm{CH}_{3} \cdots \pi$ interactions using many different $\mathrm{N}$-(o-tolyl)succinimides revealed that the preferred conformational state in solution was also retained in the solid state. ${ }^{[25 d]}$ The dependence of the strength of a face-to-face Aryl $\cdots$ Aryl alignment on the alkyl substituent $\left[\mathrm{CH}_{3}, \mathrm{C}_{2} \mathrm{H}_{5}, \mathrm{CH}\left(\mathrm{CH}_{3}\right)_{2}\right.$, and $\left.\mathrm{C}\left(\mathrm{CH}_{3}\right)_{3}\right]$, as well as its position in a phenyl ring (meta and para), 
was also evaluated. ${ }^{[25 \mathrm{~h}]}$ In another paper, Shimizu et al. studied models with deuterated and protonated alkyl groups to compare $\mathrm{CH} \cdots \pi$ and $\mathrm{CD} \cdots \pi$ pairs, though no significant differences were observed. ${ }^{[25 b]}$

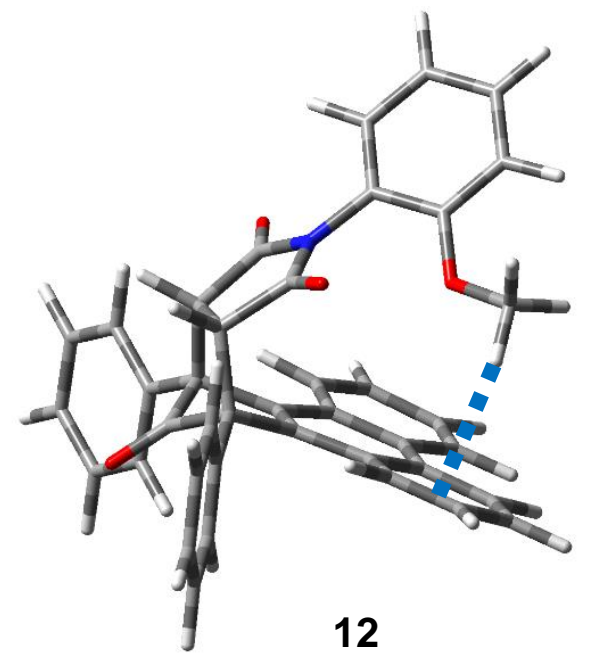

Figure 7. An example of the Shimizu balance used to study Akyl $\cdots$ Aryl interactions. ${ }^{[25 c]}$ The optimised geometry using the MMX force field ${ }^{[19 a, b]}$ for a single molecule in vacuo is shown.

Subsequently, molecular balances developed by Shimizu et al. were also employed to study parallel alignments of Pyridine $\cdots$ Benzene ring pairs (Figure 8). ${ }^{[25 a]}$ It was found that pyridine fragments with positively charged $\mathrm{N}$ atoms showed stronger attractions to aromatic rings than neutral pyridines. In addition, the position of the $\mathrm{N}$ atom in the six-membered ring was also found to be crucial. ${ }^{[25 a]}$

Recently, Shimizu et al. reported the results of their studies of Fluorine $\cdots$ Aromatic $(\mathrm{F} \cdots \pi)$ interactions using $\mathrm{N}$-arylimide molecular balances. ${ }^{[25 f]}$ In line with other studies, F $\cdots \pi$ interactions were stronger in the case of electron-deficient aromatic rings. It was found that the F $\cdots \pi$ attraction is mostly electrostatic in nature. Furthermore, they have also undertaken quantitative studies of $\mathrm{Ag} \cdots \pi$ interactions, showing that their stabilising energy falls between 5.61 and $11.00 \mathrm{~kJ} \mathrm{~mol}^{-1}{ }^{[25 \mathrm{~g}]}$ 

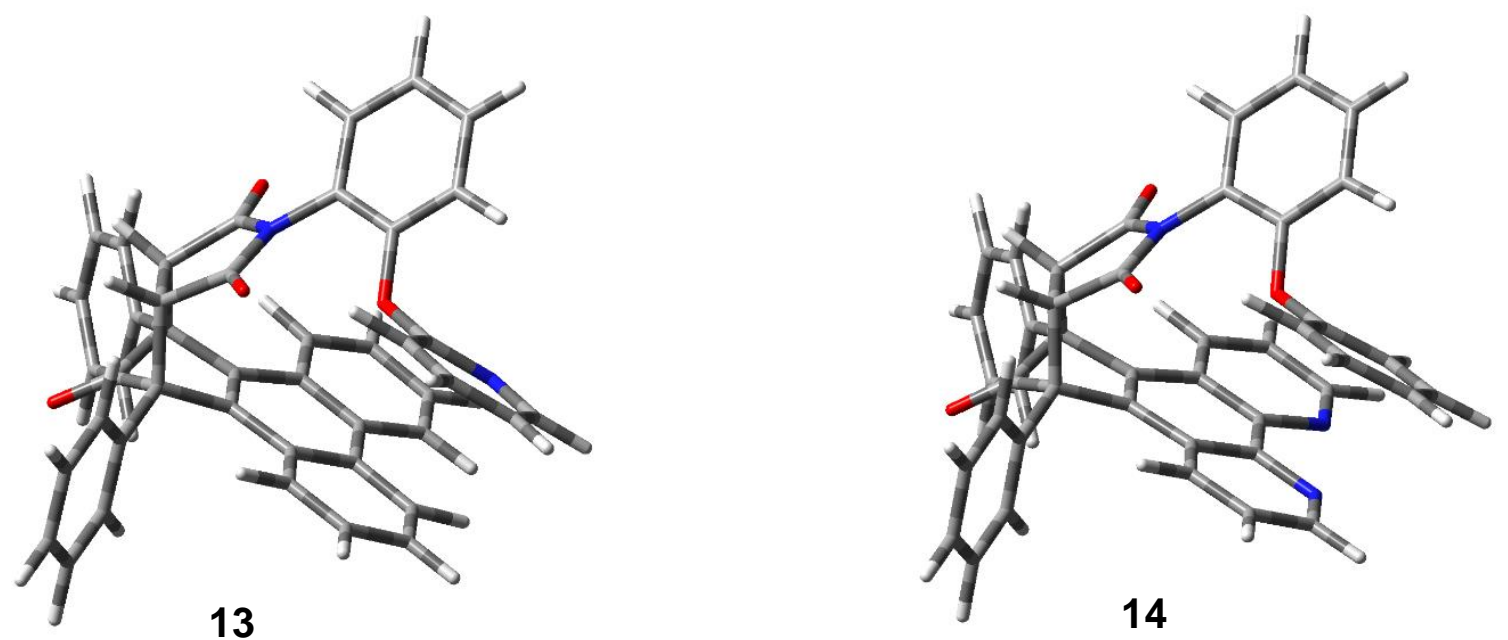

Figure 8. Examples of the Shimizu balances used to study parallel alignments of Pyridine...Benzene ring pairs. Folded conformers of $\mathbf{1 3}$ and $\mathbf{1 4}$ are shown. In cationic Nheterocycles, the nitrogen atom in 6-membered aromatic rings was replaced by $\mathrm{N}^{+} \mathrm{H}$ or $\mathrm{N}^{+} \mathrm{Me}$. Optimised geometries using the MMX force field ${ }^{[19 a, b]}$ for a single molecule in vacuo are shown.

In a further variant, Shimizu has developed a bis $\mathrm{N}$-arylimide atropisomeric molecular balance, ${ }^{[25 i]}$ based around the powerful electron withdrawing naphthalene diimide unit pioneered by Matile, ${ }^{[\mathrm{k}, 1]}$ and used it for quantitative NMR studies of Aryl $\cdots$ Aryl interactions in stacked sandwich arrangements (Figure 9). Larger aryl fragments showed much stronger Aryl $\cdots$ Aryl interactions compared to smaller aryls.

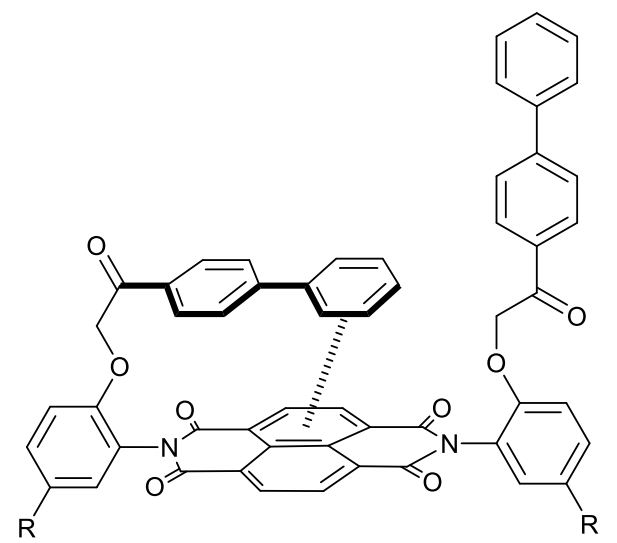

15-syn

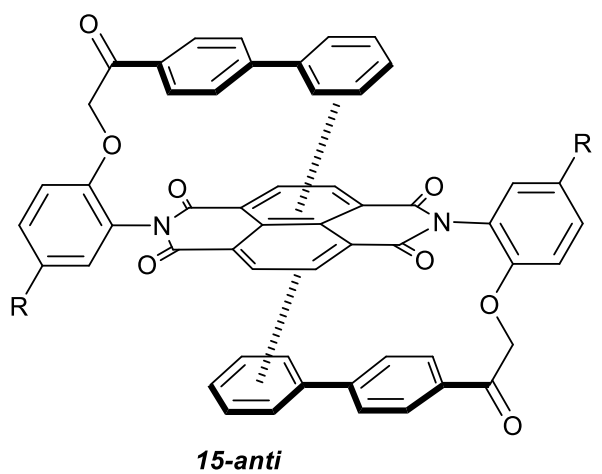

15-ant

Figure 9. An example of an atropisomeric molecular balance of Shimizu et al. ${ }^{[25 i]}$ for studies of Aryl $\cdots$ Aryl interactions in stacked sandwich arrangements ( $\mathrm{R}=$ tert-amyl). The diphenyl group was substituted with aromatic fragments of varying size. 
Most recently, following on from our detailed comparison of "oxygen versus sulphur" over a wide range of $\pi$ systems, ${ }^{[26 a, 26 e]}$ the Shimizu group have reproduced the isolated measurement previously made by Cozzi ${ }^{[22]}$ and published their own detailed study of the interactions of 18 pairs of ethers and thioethers with an extended series of polycyclic aromatics. ${ }^{[27]}$ Even although the authors were aware that the ether or thioether group is placed at shorter than the optimum distance above the aromatic surface and that this inherent steric bias favours the smaller oxygen atom, the significant observation was made that, in almost one third of the cases studied, the larger sulfur atom is favoured over the oxygen atom in the folded conformation. These observations were also supported by a detailed computational study. Thus far, neither the groups of Cozzi nor of Shimizu have reported the syntheses of $\mathrm{N}$-aryl imides in which the two flanking ortho positions contain both an ether and a thioether group. Overall, however, these observations are in agreement with those reported by Motherwell et al. ${ }^{[26 \mathrm{a}, 26 \mathrm{e}]}$ and confirm the ability of the sulfur atom to engage in stabilizing dispersion interactions with $\pi$ systems.

\section{Triptycene balances of Ōki and Gung}

Initially, Ōki et al. introduced triptycene-based molecular systems in studies of weak molecular interactions. ${ }^{[13,28]}$ Gung et al. used triptycene balances to estimate the stabilisation energy of Aryl $\cdots$ Aryl interactions in the parallel-displaced alignment. ${ }^{[29 a]}$ In these balances, the dynamic exchange between the anti rotamer and the two syn rotamers in the triptycene balance is monitored (Figure 10), as the rotation about the $\mathrm{C} 9-\mathrm{CH}_{2} \mathrm{Ph}$ bond is relatively slow in the NMR timescale at low temperatures (typically, at $-40{ }^{\circ} \mathrm{C}$ ). Theoretically, a syn/anti population ratio would be 2:1 if the aryl substituents at $\mathrm{C} 1$ and $\mathrm{C} 9$ do not interact with each other, while an Aryl $\cdots$ Aryl attraction is expected to further increase the population of the syn rotamers. Four sets of triptycenes were studied in which $\mathrm{X}=\mathrm{H}, \mathrm{CH}_{3}, \mathrm{~F}, \mathrm{CF}_{3}$ and $\mathrm{Y}=\mathrm{NO}_{2}, \mathrm{CN}, \mathrm{F}, \mathrm{Br}, \mathrm{H}, \mathrm{CH}_{3}$, $\mathrm{OCH}_{3}$ (Figure 10). The $\Delta G^{\mathrm{o}}$ values varied between +0.84 and $-4.10 \mathrm{~kJ} \mathrm{~mol}^{-1}$ in $\mathrm{CDCl}_{3}$ at 298 K. For electron-donating groups, the Aryl $\cdots$ Aryl interactions were either insignificant or marginally repulsive, whilst in the case of electron-withdrawing groups they were attractive. 

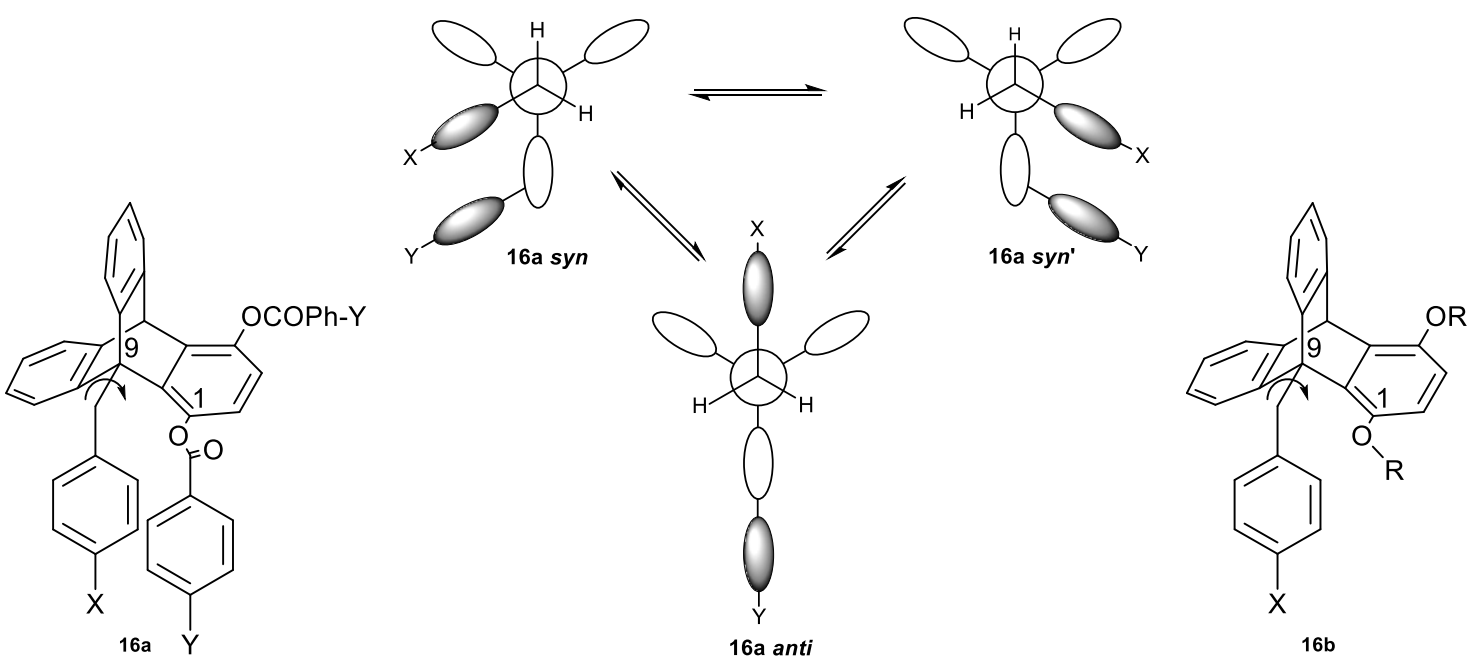

Figure 10. Illustration of the conformational equilibrium between syn and anti rotamers of triptycene derivative 16a. ${ }^{[29]}$ Triptycenes $\mathbf{1 6 b}$ with $\mathrm{R}=\mathrm{CH}_{3}, \mathrm{COH}, \mathrm{COCH}_{3}, \mathrm{COC}_{2} \mathrm{H}_{5}$, $\mathrm{COCH}\left(\mathrm{CH}_{3}\right)_{2}, \mathrm{COCF}_{3}$ and $\mathrm{X}=\mathrm{H}, \mathrm{F}, \mathrm{CN}, \mathrm{CH}_{3}, \mathrm{CF}_{3}$ were also studied. ${ }^{[29 \mathrm{~b}]}$

Triptycenes 16b (Figure 10) with $\mathrm{R}=\mathrm{CH}_{3}, \mathrm{COH}, \mathrm{COCH}_{3}, \mathrm{COC}_{2} \mathrm{H}_{5}, \mathrm{COCH}\left(\mathrm{CH}_{3}\right)_{2}, \mathrm{COCF}_{3}$ and $\mathrm{X}=\mathrm{H}, \mathrm{F}, \mathrm{CN}, \mathrm{CH}_{3}, \mathrm{CF}_{3}$ were also used to determine the strength of LP $\cdots$ Aryl forces in the off-centre arrangement. ${ }^{[29 \mathrm{~b}]}$ For $\mathrm{R}=\mathrm{Me} / \mathrm{X}=\mathrm{CF}_{3}$, a relatively strong attractive interaction was observed $\left(-1.97 \mathrm{~kJ} \mathrm{~mol}^{-1}\right)$, while for $\mathrm{R}=\mathrm{COCF}_{3} / \mathrm{X}=\mathrm{H}$ the interaction was repulsive $(+0.33$ $\left.\mathrm{kJ} \mathrm{mol}^{-1}\right)$.

In a subsequent report, Gung et al. employed triptycene balances to study the dependence of attractive parallel-displaced Aryl $\cdots$ Aryl forces on the nature of the functional group attached to the aromatic ring. ${ }^{[29 c]}$ They reported charge-transfer bands for systems with strong donors and acceptors. The $\Delta G^{\circ}$ values for Aryl $\cdots$ Aryl interactions in the presence of strong electron donating and withdrawing substituents did not show a linear dependence in the Hammett plot.

\section{Aromatic balances of Jennings}

In a quest for molecules with the edge-to-face arrangement of aromatic rings, Jennings et al. ${ }^{[30 \mathrm{a}]}$ considered four biaryls with a phenethyl side chain, which exchange slowly in the NMR timescale between two atropisomers (Figure 11a). Based on the ${ }^{1} \mathrm{H}$ NMR chemical shifts measured, it was found that the preferred atropisomer is likely to be stabilised by an edge-toface $\mathrm{CH} \cdots \pi$ interaction of the terminal phenyl ring of the side chain with the nearest proton of the naphthyl (or tolyl) fragment. The stabilisation energy of the edge-to-face attraction was 
estimated to be $\sim 6.7 \mathrm{~kJ} \mathrm{~mol}^{-1}$. As shown by X-ray and low-temperature NMR measurements, similar noncovalent interactions were also present in imines and nitrones (Figure 11b). ${ }^{[30 \mathrm{~b}]}$

In a similar fashion, Jennings et al. demonstrated that hindered rotational dynamics in imines lead to a large ${ }^{1} \mathrm{H}$ NMR chemical shift difference for the ortho protons, ${ }^{[30 \mathrm{c}]}$ which facilitated studies of the face tilted-T CH$\cdots \pi$ interaction between rings $\mathrm{A}$ and $\mathrm{B}$ (Figure 11c). Using an ortho fluoro substitution, they estimated that, enthalpically, a CF $\cdots \pi$ interaction is weaker than the $\mathrm{CH} \cdots \pi$ interaction by at least $4.2 \mathrm{~kJ} \mathrm{~mol}^{-1}$.
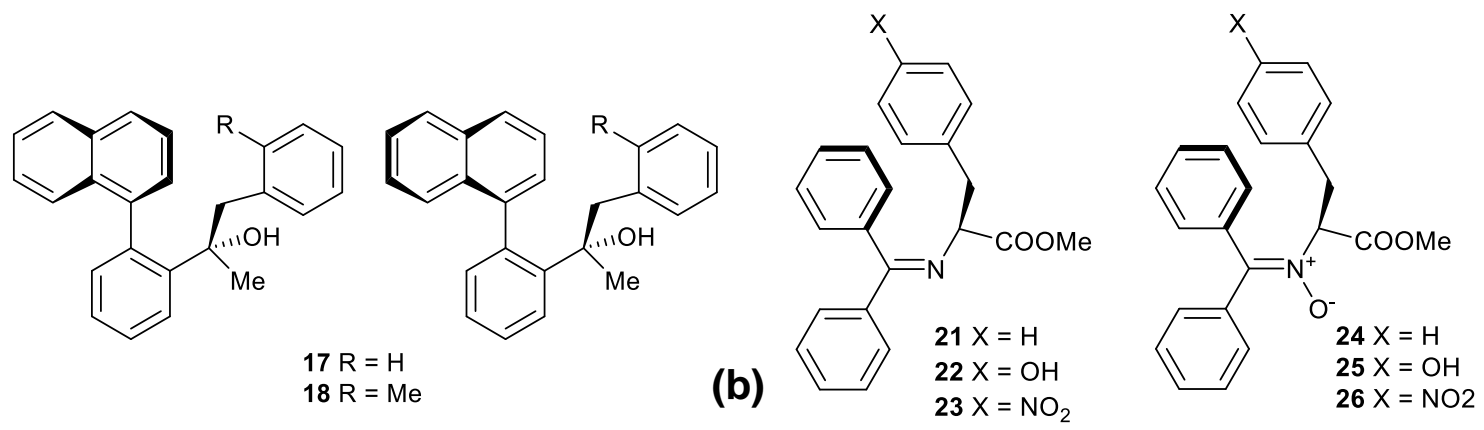

(a)
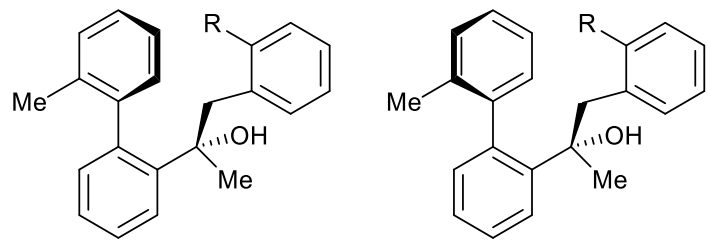

(c)

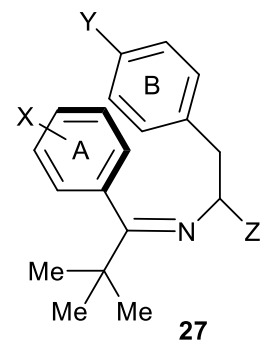

Figure 11. (a) Biaryls with a phenethyl side chain; $;^{[30 a]}$ (b) imines and nitrones; ${ }^{[30 b]}$ (c) imines $^{[30 \mathrm{c}]}$ with the face tilted-T $\mathrm{CH} \cdots \pi$ interactions between rings $\mathrm{A}$ and $\mathrm{B}$. The substituents considered for 27 were $\mathrm{X}=\mathrm{H}, \mathrm{F}, \mathrm{OMe}, \mathrm{Cl}, \mathrm{OMe}, \mathrm{Y}=\mathrm{H}, \mathrm{OH}, \mathrm{NO}_{2}$ and $\mathrm{Z}=\mathrm{Ph}, \mathrm{COOMe}$.

Most recently, Jennings et al. extended their solid-state and solution studies to heteroaromatic pyridine, furan and thiophene derivatives, showing that these can also form tilted T-shaped geometries with nearby phenyl rings. ${ }^{[30 \mathrm{~d}]}$

\section{Cockroft balances}

In order to study the dependence of noncovalent interactions on solvent and substituent effects, Cockroft and coworkers designed a series of synthetic derivatives of N,N-diphenylformamide and N-pyridyl,N-phenylformamide (Figure 12). ${ }^{[31 \mathrm{a}, \mathrm{b}]}$ A large number of experimentally derived $\Delta G^{\circ}$ values were examined using a simple solvation model, which enabled to distinguish the role of intra- and intermolecular interactions. Remarkably, the application of this new approach 
allowed Cockroft et al. to detect an unusual $\mathrm{C}=\mathrm{O} \cdots \mathrm{NO}_{2}$ interaction, with the estimated stabilisation energy of up to $3.6 \mathrm{~kJ} \mathrm{~mol}^{-1}{ }^{[31 \mathrm{~b}]}$

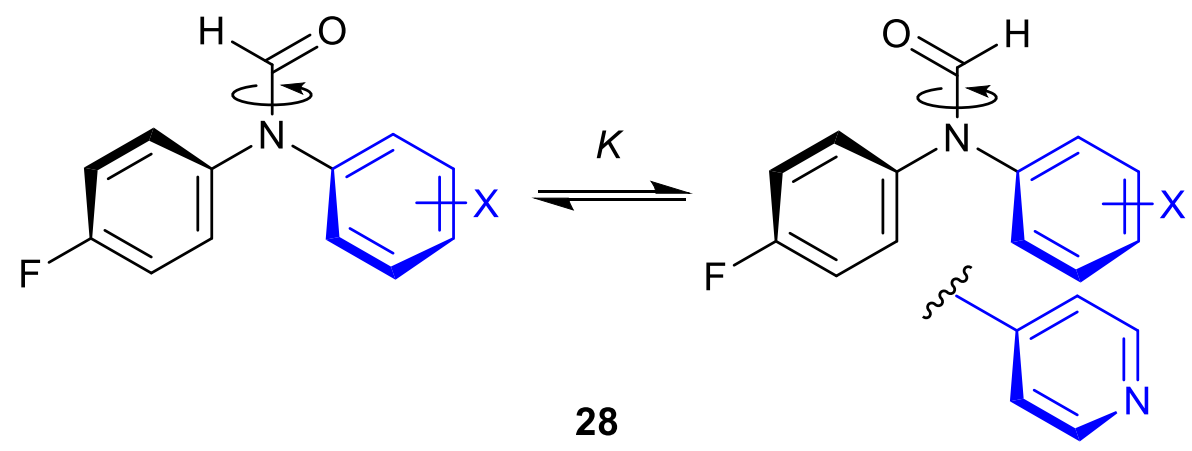

O-Conformer

H-Conformer

$\mathrm{X}=\mathrm{NEt}_{2}, \mathrm{OMe}, \mathrm{H}, \mathrm{Br}, \mathrm{COMe}, \mathrm{CF}_{3}, \mathrm{CN}, \mathrm{Ph}, \mathrm{Me}, \mathrm{NO}_{2}$

Figure 12. Formamide balances of Cockroft et al. ${ }^{[31]}$ The $\Delta G^{\mathrm{o}}$ values were determined directly from the ${ }^{19} \mathrm{~F}$ NMR spectra via integration of peaks corresponding to each conformer.

\section{Proline-based balances of Raines}

Proline is one of the most studied natural amino acids due to its unusual cyclic structure. Raines et al. initially focused on the preference of the peptide bond of the proline residue to adopt the trans conformation in polypeptides and showed that an $n \rightarrow \pi^{*}$ interaction between the peptide oxygen and the following carbonyl carbon (Figure 13a) leads to substantially stabilised structures in proteins, including collagen. ${ }^{[32 \mathrm{a}]}$ This interaction is assumed to be stabilised via an electron density donation from one of peptide oxygen LPs into the antibonding orbital of the carbonyl carbon. In a more general form, this noncovalent interaction could be denoted as a $\mathrm{C}=\mathrm{O} \cdots \mathrm{C}=\mathrm{O}$ pair.

In their subsequent report, Raines et al. showed that the trans/cis ratio in $\mathrm{N}$-formylproline 30 depends on the electron-withdrawing capability of the remote substituent $\mathrm{X}$ in the phenylester fragment (Figure 13b). ${ }^{[32 \mathrm{~b}]}$ As before, ${ }^{[32 \mathrm{a}]}$ this dependence was attributed to an $n \rightarrow \pi^{*}$ donation from the amide oxygen to the ester carbonyl carbon. ${ }^{[32 b]}$ 


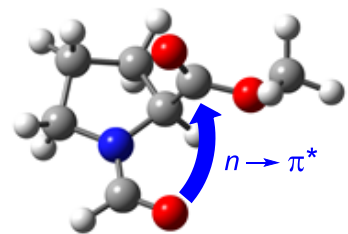

29

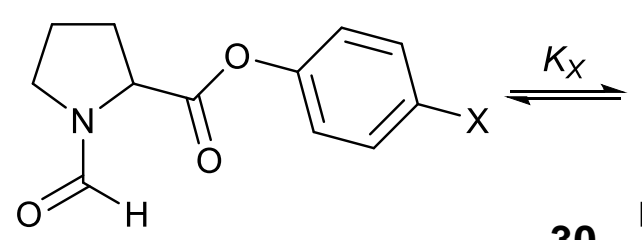

30<smiles>[X]c1ccc(OC(=O)C2CCCN2C(=O)O)cc1</smiles>

(b)

Figure 13. (a) A noncovalent interaction between carbonyl $\mathrm{O}$ and $\mathrm{C}$ atoms in N-formyl-Lproline methyl ester 29. ${ }^{[32 \mathrm{a}]}$ The optimised geometry using the MMX force field ${ }^{[19 \mathrm{a}, \mathrm{b}]}$ for a single molecule in vacuo is shown. (b) Trans/cis rotameric exchange in $\mathbf{3 0}\left(\mathrm{Fm}-\mathrm{Pro}-\mathrm{OC}_{6} \mathrm{H}_{4}-\right.$ $\left.p-\mathrm{X}, \mathrm{X}=\mathrm{H}, \mathrm{CN}, \mathrm{OMe}, \mathrm{NMe}_{2}, \mathrm{NO}_{2}\right){ }^{[32 \mathrm{~b}]}$

A proline-based balance was further explored by Raines et al. (Figure 14a) for the $\mathrm{C}=\mathrm{X} \cdots \mathrm{C}=\mathrm{O}$ interaction studies in amides $(\mathrm{X}=\mathrm{O})$ and thioamides $(\mathrm{X}=\mathrm{S}) \cdot{ }^{[32 \mathrm{c}]}$ Their results indicated that the change from $\mathrm{X}=\mathrm{O}$ to $\mathrm{X}=\mathrm{S}$ is likely to increase ligand affinity due to enhanced $n \rightarrow \pi^{*}$ electronic delocalisation. It is of course well known that separate rotamers of thioamides can often be isolated.

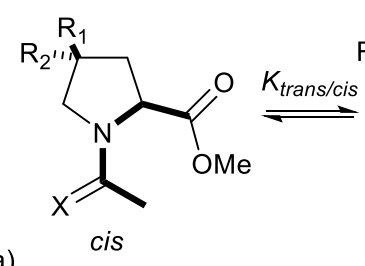

(a)

$$
\begin{aligned}
& 31 X=O, R_{1}=H, R_{2}=H \\
& 32 X=O, R_{1}=F, R_{2}=H \\
& 33 X=O, R_{1}=H, R_{2}=F
\end{aligned}
$$

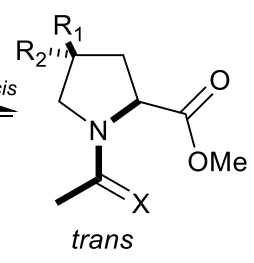

$34 \mathrm{X}=\mathrm{S}, \mathrm{R}_{1}=\mathrm{H}, \mathrm{R}_{2}=\mathrm{H}$ $35 X=S, R_{1}=F, R_{2}=H$ $36 X=S, R_{1}=H, R_{2}=F$

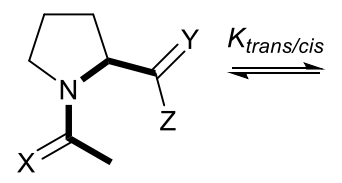

(b)

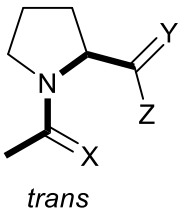

trans

$37 X=O, Y=O, Z=O M e \quad 40 X=S, Y=O, Z=N^{\prime} e_{2}$ $38 X=S, Y=O, Z=O M e \quad 41 X=O, Y=S, Z=N^{\prime} e_{2}$ $39 X=O, Y=O, Z=\mathrm{NMe}_{2} 42 X=S, Y=S, Z=\mathrm{NMe}_{2}$

Figure 14. Molecular models with a) $C=X \cdots C=O$ interactions ${ }^{[32 c]}$ and b) $C=X \cdots C=Y$ interactions. ${ }^{[32 \mathrm{~d}]}$

In their 2013 report (Figure 14b), ${ }^{[32 d]}$ Raines et al. estimated that the stabilisation energy of the $\mathrm{C}=\mathrm{O} \cdots \mathrm{C}=\mathrm{O}$ interaction in 39 is at least $1.13 \mathrm{~kJ} \mathrm{~mol}^{-1}$. Most remarkably, the $\mathrm{C}=\mathrm{S} \cdots \mathrm{C}=\mathrm{S}$ interaction in $\mathbf{4 2}$ was found to be three-fold stronger than the $\mathrm{C}=\mathrm{O} \cdots \mathrm{C}=\mathrm{O}$ interaction in $\mathbf{3 9}$. This finding is particularly useful for the process of lead optimization in medicinal chemistry, as the backbone thioamide insertion could stabilise protein structures. ${ }^{[32 \mathrm{c}, \mathrm{d}]}$ Subsequently, many other examples demonstrating the role of the $n \rightarrow \pi^{*}$ interactions in proteins were reported by Raines et al. ${ }^{[32 \mathrm{e}-1]}$

\section{Bicyclononane balances of Motherwell}


Our own interest in this area arose as a consequence of a research programme to develop a novel approach to artificial "millipede" enzymes. ${ }^{[33]}$ At that time, we were very fortunate to have Miloslav Nič as a $\mathrm{PhD}$ student in our research group and his insight led to the introduction of the dibenzobicyclo[3.2.2.]nonane scaffold as a valuable template for comparison and ranking of Aryl $\cdots \mathrm{Z}(\mathrm{Y})$ interactions, where $\mathrm{Z}$ and $\mathrm{Y}$ are various functional groups. ${ }^{\left[{ }^{[26 a]} \text { Within }\right.}$ this framework, which was inspired by the early studies of tribenzobicyclo[4.2.2.] decanes, ${ }^{[34]}$ functional groups $\mathrm{Z}$ and $\mathrm{Y}$ are attached to the central carbon atom of the 9,10-propano bridge (Figure 15). The latter is introduced to rigidize the aromatic base by excluding the possibility of "butterfly" motion typical for 9,10-dihydroanthracenes. Thus, the remaining mobile point is the central carbon of the propano bridge which oscillates like a pendulum, placing either $\mathrm{Z}$ or $\mathrm{Y}$ in close proximity of the benzene ring (Figure 16). Unlike the $\mathrm{N}$-arylimide torsional balances, this framework can nevertheless tolerate a larger atom such as sulfur without steric impediment. Effectively, so much is the same on both sides of the exchange between the down (D) and up (U) alignments (Figure 15), that this molecular skeleton can operate as a perfect balance for quantitative comparison and ranking of $\pi$-interaction strengths.

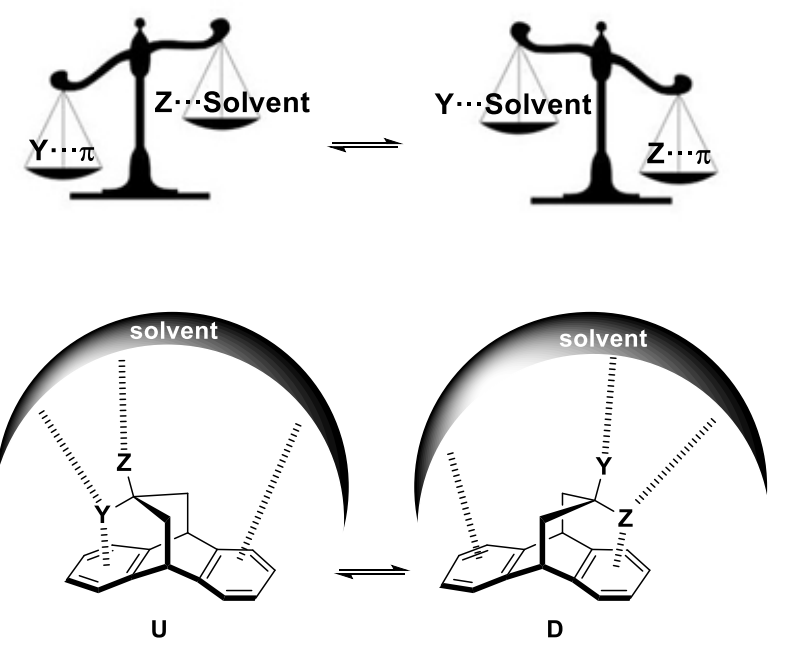

Figure 15. A two-site conformational exchange in Motherwell balances. Down and up alignments of the more electronegative substituent $\mathrm{Z}$ are used to distinguish two conformers as "D" and "U", respectively.

It should be noted that in contrast to conformationally more heterogeneous frameworks such as Wilcox balances, ${ }^{[14]}$ the two $\mathrm{Z}$ and $\mathrm{Y}$ substituents are restricted to adopt unique orientations towards the aromatic ring in bicyclononanes (Figure 15), since excluded are those Aryl $\cdots \mathrm{Z}(\mathrm{Y})$ interaction geometries in which the balance backbone on the Aryl side is significantly modified 
to afford a stronger noncovalent bond. As the conformational equilibrium between $\mathrm{D}$ and $\mathrm{U}$ forms is fast in the NMR chemical shift timescale, the observed averaged vicinal coupling constants of the aliphatic protons of the bicyclononane fragment were used for quantitative analysis. From $\bar{J}=J^{\mathrm{D}} p_{\mathrm{D}}+J^{\mathrm{U}} p_{\mathrm{U}}$, where $J^{\mathrm{D}}$ and $J^{\mathrm{U}}$ are the boundary $J$ couplings in D and U sites and $\bar{J}$ is the observed averaged $J$ coupling, the populations of conformers ( $p_{\mathrm{D}}$ and $p_{\mathrm{U}}=1-p_{\mathrm{D}}$ ) can be determined. In order to determine $J^{\mathrm{D}}$ and $J^{\mathrm{U}}$, variable temperature measurements were necessary. In addition, measurements in different solvents were carried out. Other coupling constants, such as long-range couplings between protons and vicinal couplings between ${ }^{13} \mathrm{C}$ and ${ }^{1} \mathrm{H}$ nuclei, were also used to establish the preferred orientation of, for example, the hydroxyl group above the aromatic ring. ${ }^{[26 \mathrm{~b}]}$

By systematic variations of $\mathrm{Z}$ and $\mathrm{Y}$ (Figure 15) and measurements of the conformer populations, valuable insights into the comparative strengths of noncovalent interactions can be acquired. It is essential to acknowledge that this cyclic scaffold is a top pan or seesaw balance (as opposed to a torsion balance), since the Aryl $\cdots \mathrm{Z}$ interaction of one aromatic ring is being evaluated against the Aryl $\cdots Y$ interaction of the other.

Our initial studies used the simple tertiary alcohol $(\mathrm{Z}=\mathrm{OH}, \mathrm{Y}=\mathrm{Me})$ in a variety of solvents and revealed that the expected $\pi$-facial intramolecular hydrogen bond to the aromatic ring could compete effectively with Solute...S Solvent interactions (Table 1), even in solvents known as hydrogen bond acceptors (e.g., in pyridine). Moreover, an introduction of a fluorine atom instead of the hydroxyl group $(\mathrm{Z}=\mathrm{F}, \mathrm{Y}=\mathrm{Me})$ allowed a direct comparison to be made (Table 1) and demonstrated the essentially solvophobic nature of this functional group.

Table 1. The $\mathrm{OH}-$ down conformer population $\left(p_{\mathrm{D}}\right.$, in $\left.\%\right)$ at $298 \mathrm{~K}$ in balances shown in Figure 15.

\begin{tabular}{|c|c|c|}
\hline Solvent & $\mathbf{Z}=\mathbf{O H}, \mathbf{Y}=\mathbf{M e}^{[26 c]}$ & $\mathbf{Z}=\mathbf{F}, \mathbf{Y}=\mathbf{M e}^{[26 a]}$ \\
\hline $\mathrm{CDCl}_{3}$ & 94 & 95 \\
\hline $\mathrm{C}_{6} \mathrm{D}_{6}$ & 91 & 87 \\
\hline $\mathrm{CD}_{3} \mathrm{CN}$ & 76 & 97 \\
\hline $\mathrm{CD}_{3} \mathrm{OD}$ & 52 & 88 \\
\hline $\mathrm{Py}_{-} \mathrm{d}_{5}$ & 46 & - \\
\hline $\mathrm{DMSO}_{6} \mathrm{~d}_{6}$ & 43 & 93 \\
\hline
\end{tabular}

As only a few groups have studied alkene $\pi$-interactions, ${ }^{[11,35]}$ we have used the inherent symmetry of the bridged bicyclic system to design a modified balance for comparison of the 
interactions of alkenes and arenes. ${ }^{[26 c]}$ The "alkene versus arene" measurements were carried out using the basic framework of the balances shown in Figure 16 which can be used to form double mutant cycles.

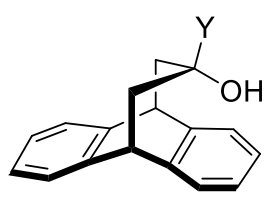

43

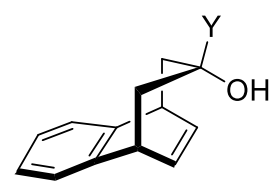

44

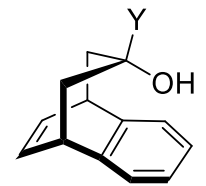

45

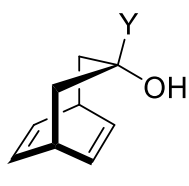

46

Figure 16. Molecular balances 43 - $46\left(\mathrm{Y}=\mathrm{H}, \mathrm{CH}_{3}, \mathrm{CH}_{2} \mathrm{CH}_{3}, \mathrm{CH}=\mathrm{CH}_{2}, \mathrm{C} \equiv \mathrm{CH}, \mathrm{C} \equiv \mathrm{N}\right)$

Thus, as demonstrated in Figure 17, the systematic variation of the counterbalancing Y substituent then leads to four internally consistent measurements of the $\mathrm{OH} \cdots$ Arene interaction strength relative to that of the $\mathrm{OH} \cdots$ Alkene pair through the use of a triple mutant cycle. The results showed that a $\pi$-facial hydrogen bond $\mathrm{OH} \cdots$ Arene is preferred by $\sim 1.2 \mathrm{~kJ} \mathrm{~mol}^{-1}$ compared to the $\mathrm{OH} \cdots$ Alkene interaction. To our initial surprise, the strongest interactions with both the aromatic ring and the double bond were observed for the cyano group. A correlation was observed between the stabilisation energy and the charge of the $\mathrm{C}^{\alpha}$ atom in substituents $\mathrm{CH}_{2} \mathrm{CH}_{3}, \mathrm{CH}=\mathrm{CH}_{2}, \mathrm{C} \equiv \mathrm{CH}$ and $\mathrm{C} \equiv \mathrm{N}$, indicating to the importance of the electrostatic component in their $\pi$-interactions. 


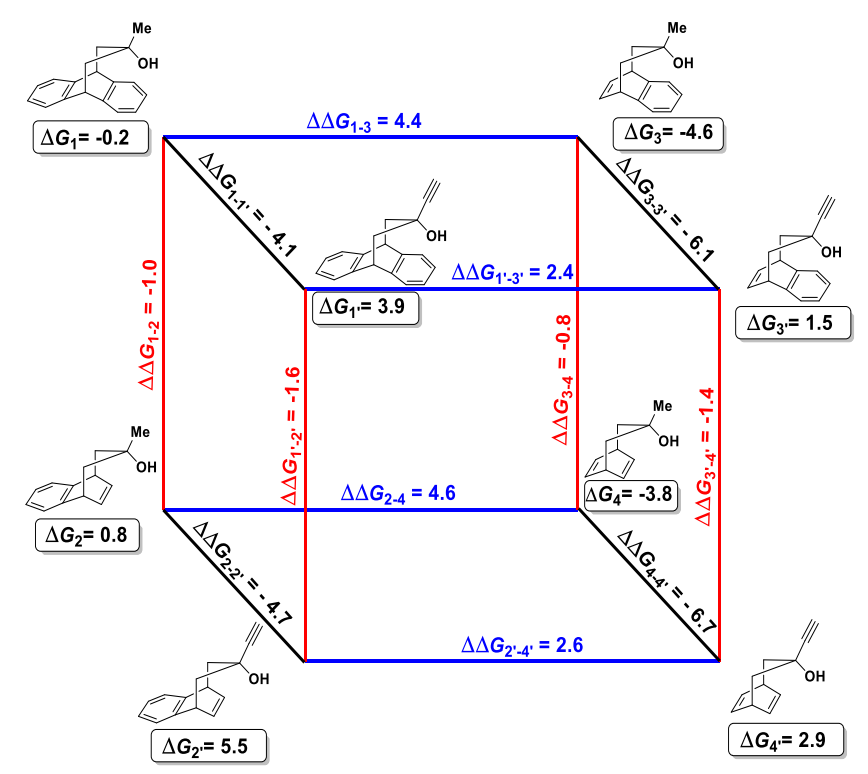

Figure 17. Experimental free energy differences in methanol (in $\mathrm{kJ} \mathrm{mol}^{-1}$ ). The $\Delta \Delta G$ values in for $\mathrm{OH} \cdots$ Arene and $\mathrm{OH} \cdots$ Alkene interactions are shown on the red edges. The unfavourable Y...Alkene interactions relative to Y...Arene interactions are shown in blue with those for the $\mathrm{CH}_{3}$ group $\left(4.5 \pm 0.1 \mathrm{~kJ} \mathrm{~mol}^{-1}\right)$ being significantly higher than for the $\mathrm{C} \equiv \mathrm{CH}$ group $(2.5 \pm 0.1 \mathrm{~kJ}$ $\left.\mathrm{mol}^{-1}\right)$. The $\left(\mathrm{CH}_{3}\right)$-to- $(\mathrm{C} \equiv \mathrm{CH})$ replacement is favoured (shown in black), both for Y $\cdots$ Arene (by $4.4 \pm 0.3 \mathrm{~kJ} \mathrm{~mol}^{-1}$ ) and Y $\cdots$ Alkene (by $6.4 \pm 0.3 \mathrm{~mol}^{-1}$ ) pairs.

In a similar fashion, replacement of one of the aromatic rings in the bicyclononane balance by an aromatic heterocycle allowed to compare and rank the interactions of a hydroxyl group with benzene, pyrazine and quinoxaline rings (Figure 18). ${ }^{[26 \mathrm{~d}]}$

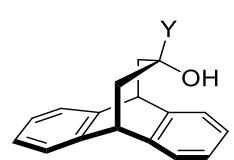

47

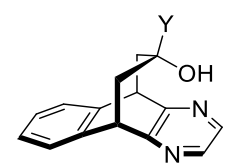

48

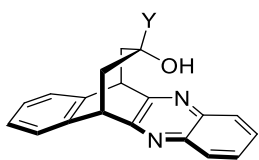

49

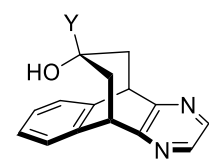

50

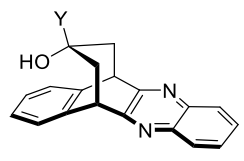

51

Figure 18. Molecular balances used to characterise noncovalent interactions of a hydroxyl group with carbo- and heteroaromatic rings ( $\mathrm{Y}=\mathrm{CH}_{3}, \mathrm{CH}_{2} \mathrm{CH}_{3}, \mathrm{CH}=\mathrm{CH}_{2}, \mathrm{C} \equiv \mathrm{CH}$ or $\mathrm{C} \equiv \mathrm{N}$ ).

The results revealed that the noncovalent $\mathrm{OH} \cdots$ Pyrazine and $\mathrm{OH} \cdots$ Quinoxaline interactions include a strong LP...Heteroarene interaction (relative to LP... Arene pair) which is very nearly solvent independent. Analogs of $\mathbf{4 8}$ and 49, where both the $\mathrm{Y}$ and $\mathrm{OH}$ groups are replaced with fluorine atoms, were also considered and it was found that both the F...Pyrazine and F...Quinoxaline interactions are favoured over the F...Benzene interaction. Remarkably, 
model 51 with $\mathrm{Y}=\mathrm{CCH}$ showed a strong $\mathrm{C} \equiv \mathrm{CH} \cdots$ Quinoxaline attraction, which was found to significantly outweigh the competing $\mathrm{OH} \cdots$ Arene interaction in $\mathbf{5 1}$.

The advantages of the bicyclo[3.2.2.]nonane scaffold were further demonstrated in a comparative study of $\mathrm{O} \cdots \pi$ and $\mathrm{S} \cdots \pi$ noncovalent interactions (Figure 19). ${ }^{[26 e]}$

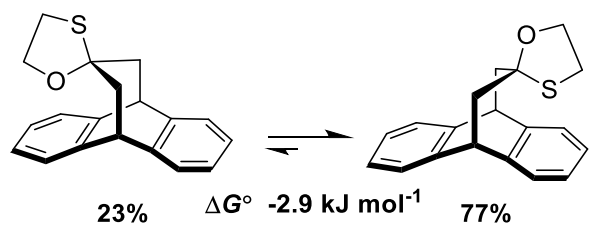

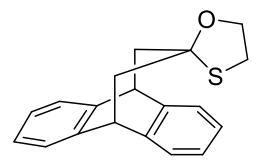

52

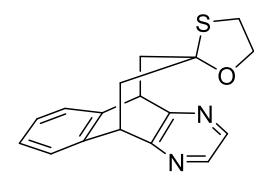

56

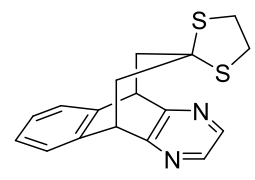

60

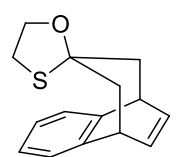

53

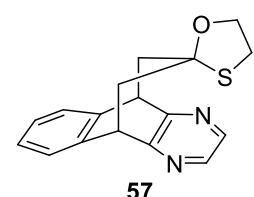

57

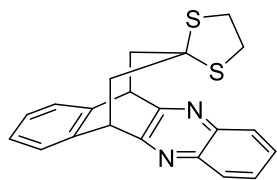

61

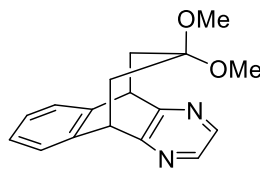

64

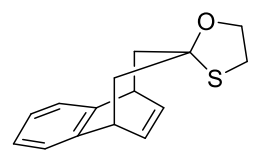

54

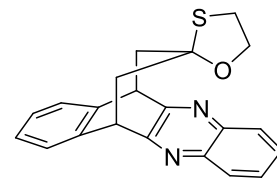

58

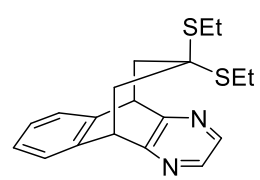

62

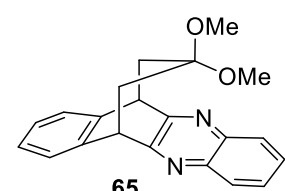

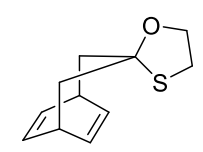

55

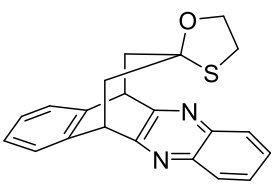

59

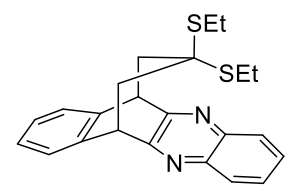

63

Figure 19. Molecular balances $52-\mathbf{6 5}$ used in studies of $\mathrm{O} \cdots \pi$ and $S \cdots \pi$ interactions. The structure of the preferred conformer is shown in each case.

From a quantitative comparative analysis of $\Delta G^{\circ}$ values, as well as $\Delta \Delta G^{\circ}$ values obtained from pairwise comparisons, it was revealed that the relative energies of $\mathrm{O} \cdots$ Alkene, O $\cdots$ Arene,

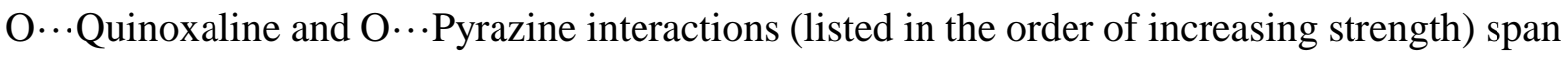
over $7.7 \mathrm{~kJ} \mathrm{~mol}^{-1}$ (8.1 kJ mol${ }^{-1}$ from DFT calculations). The corresponding energy band for

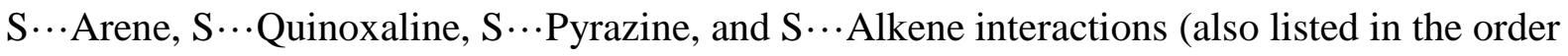
of increasing strength) was only $1.7 \mathrm{~kJ} \mathrm{~mol}^{-1}\left(3.0 \mathrm{~kJ} \mathrm{~mol}^{-1}\right.$ from DFT calculations). ${ }^{[26 \mathrm{e}]}$ Based on these results, the sulfur atom was referred to as an "atomic chameleon", since it can interact 
nearly equally with arene, heteroarene and alkene fragments, regardless how poor or rich their $\pi$-electron densities are. ${ }^{[26 e]}$ Such a behaviour of the sulfur atom was attributed to its significantly higher polarisability compared to oxygen, as well as to the availability of vacant orbitals. From the analysis of the available data for the oxygen atom, ${ }^{[26 e]}$ it was deduced that the electrostatic component may prevail in their interactions with $\pi$ systems. Similar to the interaction observed for a pair of methane molecules, ${ }^{\left[{ }^{[8]}\right.}$ additional $\mathrm{H} \cdots \mathrm{H}$ interactions were also identified between hydrogen atoms of the propano bridge $\mathrm{CH}_{2}$ groups and those of either the $\mathrm{SCH}_{2}$ (in 62 and 63 ) or $\mathrm{OCH}_{3}$ groups (in 64 and 65 ).

\section{Other balances}

In addition to the molecular balances considered above, there have been reports describing other balances, although they have not been used as widely as those considered in previous sections. Based on the aforementioned bicyclo[4.2.2] skeleton, ${ }^{[34]}$ Yamada et al. ${ }^{[39]}$ developed a molecular seesaw balance to study Aryl...Pyridinium interactions. Similar to balances of Motherwell, ${ }^{[26]}$ a two-site fast exchange (in the NMR timescale) between conformers A and B (Figure 20) was analysed using NMR $J$ couplings and the preference of conformer A was established.
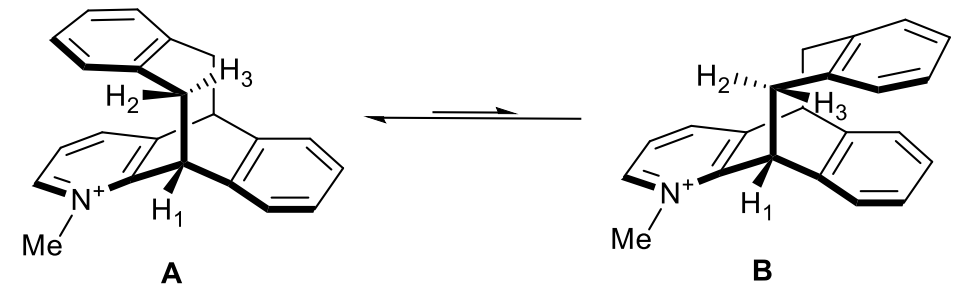

66

Figure 20. A seesaw balance of Yamada et al. ${ }^{[39]}$ Vicinal ${ }^{3} J_{\mathrm{HH}}$ couplings of protons $\mathrm{H}_{1}, \mathrm{H}_{2}$ and $\mathrm{H}_{1}, \mathrm{H}_{3}$ were used for estimating populations of conformer $\mathrm{A}$ and $\mathrm{B}$.

A diphenylacetylene molecular balance was presented by Hamilton et al. ${ }^{[40]}$ for establishing the dependence of the hydrogen bond strength on the para- $\mathrm{R}^{1} / \mathrm{R}^{2}$ substitutions (Figure 21) and for delineating the stereoelectronic components of the interaction. 


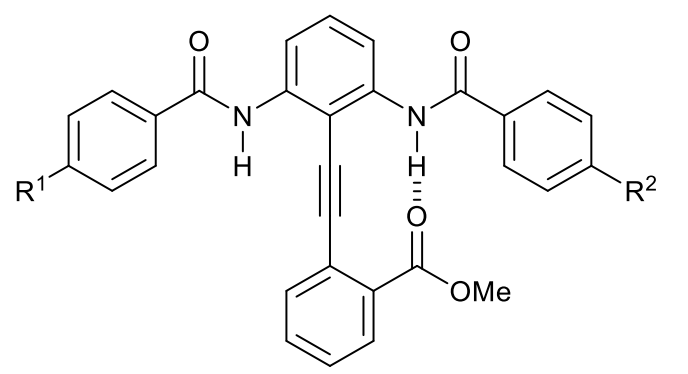<smiles>[R]c1ccc(C(=O)N([2H])c2cccc(N(C)C(=O)c3ccc([R])cc3)c2C#Cc2ccccc2C(=O)OC)cc1</smiles>

67

Figure 21. A molecular balance of Hamilton et al. ${ }^{[40]}$ with two donors competing for a single acceptor. Various combinations were considered, where $\mathrm{R}^{1}=\mathrm{H}, \mathrm{NMe}_{2}, \mathrm{OMe}$ and $\mathrm{R}^{2}=\mathrm{H}, \mathrm{Cl}$, $\mathrm{NO}_{2}$.

Lypson and Wilcox reported a new molecular balance for the assessment of pairwise amino acid interactions in antiparallel $\beta$-sheets (Figure 22). ${ }^{[41]}$ They aimed at optimising the mutual arrangement of the amino acid chains attached to aromatic rings in order to control hydrogen bond formation, although the molecular balance considered is relatively complex in terms of a large number of conformations it could potentially adopt. Furthermore, as previously emphasised, molecular balances with a relatively large number of highly polar bonds are likely to display additional noncovalent interactions, which are difficult to account for fully, especially in solution.

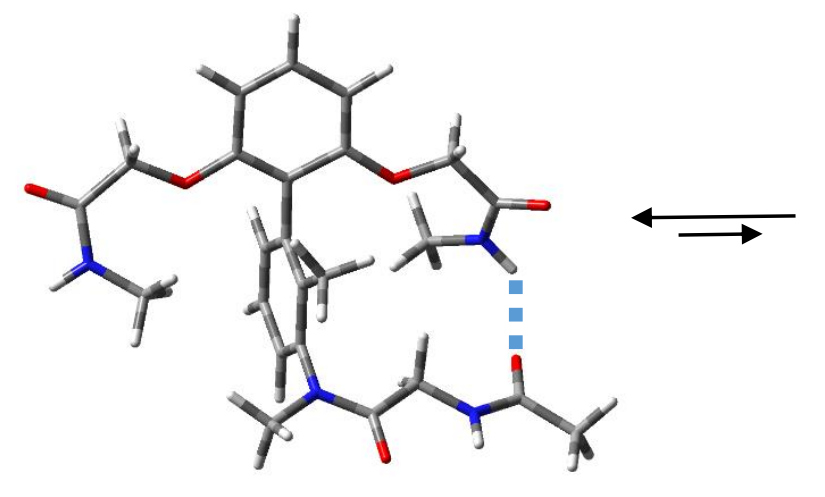

68

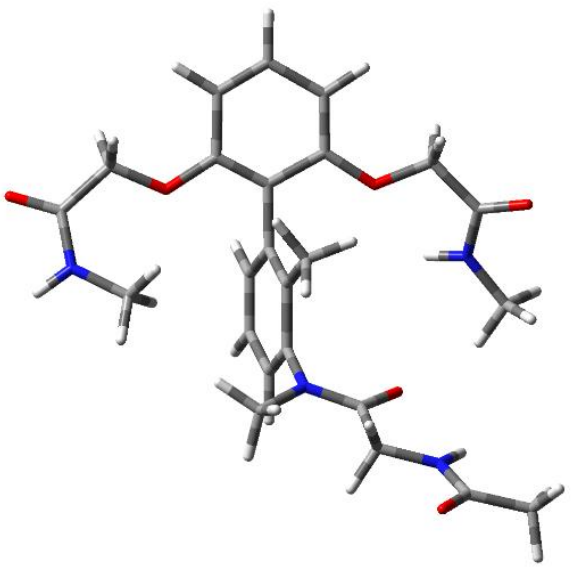

Figure 22. An example of a $\beta$-turn molecular balance of Lypson and Wilcox. ${ }^{[41]}$ Optimised geometries using the MMX force field ${ }^{[19 a, b]}$ for a single molecule in vacuo are shown.

Cornago et al. ${ }^{[42]}$ reported experimental and theoretical studies of molecular balances based on pyrazoles, which could exist in two different tautomeric forms (Figure 23). This ingenious use of tautomeric equilibria is certainly deserving of future applications in molecular balance design. 

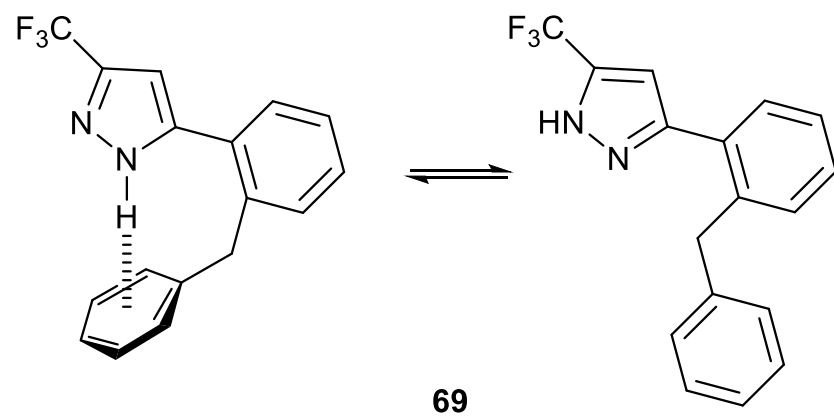

Figure 23. A pyrazole-based molecular balance of Cornago et al. ${ }^{[42]}$

Finally, other model systems have also been described in the literature which were designed for studies of noncovalent interactions in such a specific area as DNA replication. ${ }^{[43]}$ These are usually not referred to as "molecular balances", though to a certain degree they can be considered as such. For example, Eric Kool and coworkers have carried out extensive studies aimed at establishing the reasons behind the stability of the DNA double helix by the replacement of the Watson-Crick base-pairs with other "base" molecules. Specifically, a DNA duplex ( $5^{\prime}$-dXCGCGCG $)_{2}$ was considered in one of their most cited reports, ${ }^{[43 \mathrm{~b}]}$ where $\mathrm{X}$ is an unpaired deoxynucleoside with a varying aromatic "base", in order to study the forces stabilising aromatic stacking in an aqueous solution. It was found that adding a residue $\mathrm{X}$ can additionally stabilise the duplex by up to $-14.2 \mathrm{~kJ} \mathrm{~mol}^{-1}$ when the aromatic "base" in $\mathrm{X}$ is either pyrene or 5-nitroindole. ${ }^{[43 \mathrm{~b}]}$ To a certain degree, the DNA model duplexes of Kool et al. could be considered as molecular balances, though such relatively large molecules can potentially exhibit higher levels of both the conformational and tautomeric freedom in solution making them rather complex systems in terms of an unambiguous separation of distinct noncovalent contributions to the structural stabilisation.

\section{Conclusions}

In summary, the foregoing overview has hopefully indicated that a very considerable body of quantitative data into the strength of noncovalent interactions in a wide variety of solvents can be gained through the scrupulous design of synthetic molecular balances. In addition, as we, and others, have noted, it is also possible to discover new and powerful ones. It is also significant to note that measurements of a single noncovalent interaction made using different molecular balances often converge to the same answer. 
However, in the course of preparing this review, it has certainly become apparent that it is extremely difficult to "dissect out" a single noncovalent interaction for study. Even simple model molecules can show a multiplicity of intramolecular noncovalent interactions acting in a combined fashion, such as the well-known Wilcox balance (Figure 3) ${ }^{[14]}$ or our own balance showing additional $\mathrm{H} \cdots \mathrm{H}$ interactions. ${ }^{[26 \mathrm{e}]}$ It is therefore essential to undertake a comprehensive computational analysis (as opposed to the back-of-the-envelope drawings!) in order to identify all possible noncovalent interactions in a selected molecular balance prior to a quantitative experimental assessment of the strength of a particular noncovalent interaction.

The computational analysis which we presented in Figure 3 for the optimised geometries of the folded and unfolded conformers of the Wilcox balance is qualitative and relies on the assumption that the shorter the distance for the noncovalent pair considered the stronger the corresponding interaction is. It nevertheless reveals important close contacts overlooked previously, thus allowing us to avoid erroneous assignment of relatively strong noncovalent interactions defining the preferred geometries of folded and unfolded conformers. In future work, advanced theoretical approaches which have been developed in recent years should certainly be employed and could ultimately provide much-needed energy partitioning and quantitative characterisation of the relative strengths of noncovalent interactions in molecular balances, thus providing an improved approach for their design. A method known as Interacting Quantum Atoms is promising in this regard, as it allows to partition the total energy into intraand interatomic terms. ${ }^{[44 a]}$ This method has already been applied successfully by Popelier et al. for gaining insight into the fluorine gauche effect, ${ }^{[44 b]}$ the rotational barrier in biphenyl ${ }^{[44 c]}$ and other problems. ${ }^{[18 \mathrm{~d}, 44 \mathrm{~d}, \mathrm{e}]}$ In passing, it is of interest to note that their statement viz. "Much chemical insight ultimately comes down to finding out which fragment of a total system behaves like the total system, in terms of an energy profile" ${ }^{[44 d]}$ is also pertinent to molecular balances, since they are designed to dissect out a single noncovalent interaction defining the behaviour of the molecule as a whole.

In addition to the need for perceptive computational techniques when using a molecular balance, there are also experimental approaches which should be adopted wherever possible. The creation of a double or triple mutant cycle for example, ${ }^{[5 c]}$ can be successfully applied for dissecting individual noncovalent forces from the range of weak interactions present in a molecule (see, for example, Figure 17 above). Another approach lies in careful systematic structural modification of the molecular framework (i.e. introduce "control balances" ${ }^{[25 j]}$ in 
order to remove or modify a particular interaction. Certain assumptions have to be made in such cases, e. g., it is assumed that the geometry of the molecular framework does not undergo significant changes on replacing one fragment with another. While some of these assumptions are justifiable, nonetheless some verification must be provided. For example, a replacement of an aromatic ring with a double bond in a control balance may not lead to a removal of intramolecular Substituent $\cdots \pi$ interactions, as it was assumed by Shimizu et al. ${ }^{[25 \mathrm{j}]}$ since the interactions of the $\pi$ (Aromatic) fragment in the main molecular balance are replaced by those of the $\pi$ (Olefinic) fragment, as shown by us previously. ${ }^{[26 c]}$

The overview of molecular balances presented above indicates to the abundance of $\mathrm{CH} \cdots \pi$ interactions. They are virtually impossible to avoid! As we have shown previously, ${ }^{[26]}$ in top pan or seesaw balances it is often the balance between the Heteroatom $\cdots \pi$ and $\mathrm{CH} \cdots \pi$ interactions that needs to be analysed. Yet very often the importance of these $\mathrm{CH} \cdots \pi$ interactions are overlooked, while their very large numbers in organic and bioorganic species, rather than their individual relative strengths, may become a more decisive factor than an isolated Heteroatom $\cdots \pi$ or Polar $\cdots \pi$ interaction in determining the overall geometry of the preferred conformer. As a well-known example, highly accurate computational studies of intermolecular noncovalent interactions in a benzene dimer have revealed that, in comparison to the stacked sandwich geometry, the virtually isoenergetic parallel-displaced and T-shaped geometries provide the most stable arrangements, and both of these provide optimum geometries for $\mathrm{CH} \cdots \pi$ close contacts. ${ }^{[45]}$

Finally, on the matter of the precision of the language used, it is a tribute to the influence of Wilcox that the words "torsion" and "molecular balance" seem to have become inextricably linked and, in consequence, even our own top pan or seesaw balance has been referred to in these terms. In similar fashion, there are authors who use a top pan molecular balance in their graphical abstract, even although their work involves a torsion balance! As emphasised by Mati and Cockroft, ${ }^{[16]}$ it is easier to interpret the free energy differences between conformers in their ground state as in the top pan molecular balance than it is in the case of the barrier to rotation around a single bond which measures the free energy difference between the ground and transition states.

Many exciting opportunities certainly exist for the design of further new balances to quantify and dissect the relative strengths of noncovalent interactions as a function of solvation and the importance of the many factors which contribute to overall molecular recognition. Although 
this approach is only one of many within a vastly multidisciplinary field of research, both the scrupulous experiments and rigorous computations are likely to converge into a single consistent approach as to how each type of interaction can be neatly dissected and quantified By measuring a single isolated noncovalent interaction using a molecular balance in a quantitative way, the library of data obtained is hopefully paving the way for improved theoretical methods in areas such as solvation, and even more so, for the ultimate ability to predict the exact nature of a molecular recognition event which can involve several noncovalent interactions, as in drug design, organocatalysis or enzyme substrate binding and transition state stabilisation.

\section{Acknowledgements}

We wish to thank our reviewers for their insightful and stimulating comments. We also acknowledge support by EPSRC (EP/P020410/1).

\section{References}

[1] a) C. A. Hunter, Angew. Chem. Int. Ed. Engl. 1993, 32, 1584-1586. b) K. Müller-Dethlefs, P. Hobza, Chem. Rev. 2000, 100, 143-168. c) W. B. Jennings, B. M. Farrell, J. F. Malone, Acc. Chem. Res., 2001, 34, 885-894. d) T. Steiner, Angew. Chem. Int. Ed. Engl. 2002, 41, 48-76. e) S. Tsuzuki, Struc. Bond. 2005, 115, 149-193. f) J. Černý, P. Hobza, Phys. Chem. Chem. Phys. 2007, 9, 5291-5303.

[2] a) A. I. Kitaygorodsky, Molecular Crystals and Molecules, Academic Press, New York, 1973. b) J.N. Israelachvili, Intermolecular and surface forces, Academic Press, San Diego, 1992. c) C. Branden, J. Tooze, Introduction to Protein Structure, Garland Publishing, New York, 1999. d) G. Desiraju, T. Steiner, The Weak Hydrogen Bond: Applications to Structural Chemistry and Biology, Oxford Univ Press, 1999, pp. 185-190.

[3] a) V. G. H. Lafitte, A. E. Aliev, P. N. Horton, M. B. Hursthouse, H. C. Hailes, Chem. Commun. 2006, 2173 2175. b) A. D. Hughes, E. V. Anslyn, Proc. Natl. Acad. Sci. U. S. A. 2007, 104, 6538-6543. c) C. A. Hunter, H. L. Anderson, Angew. Chem., Int. Ed. 2009, 48, 7488- 7499. d) A. S. Mahadevi, G. N. Sastry, Chem. Rev. 2016, 116, 2775-2825.

[4] a) C. A. Hunter, J. K. M. Sanders, J. Am. Chem. Soc. 1990, 112, 5525-5534. b) J. H. Williams, Acc. Chem. Res. 1993, 26, 593-598.

[5] a) W. B. Jennings, B. M. Farrell, J. F. Malone, Acc. Chem. Res. 2001, 34, 885-894. b) E. A. Meyer, R. K. Castellano, F. Diederich, Angew. Chem. Int. Ed. Engl. 2003, 42, 1210-1250; Angew. Chem. 2003, 115, 12441287. c) S. L. Cockroft, C. A. Hunter, Chem. Soc. Rev. 2007, 36, 172-188. d) H.-J. Schneider, Angew. Chem. Int. Ed. 2009, 48, 3924-3977; Angew. Chem. 2009, 121, 3982-4036. e) L. M. Salonen, M. Ellermann, F. Diederich, Angew. Chem. Int. Ed. 2011, 50, 4808-4842; Angew. Chem. 2011, 123, 4908-4944. f) F. Biedermann, W. M. Nau, H.-J. Schneider, Angew. Chem. Int. Ed. 2014, 53, 11158-11171; Angew. Chem. 2014, 126, 11338-11352. g) E. Persch, O. Dumele, F. Diederich, Angew. Chem. Int. Ed. 2015, 54, 3290-3327; Angew. Chem. 2015, 127 , 
3341-3382. h) J. P. Wagner, P. R. Schreiner, Angew. Chem. Int. Ed. 2015, 54, 12274-12296; Angew. Chem. 2015, $127,12446-12471$.

[6] a) F. Cozzi, M. Cinquini, R. Annunziata, T. Dwyer, J. S. Siegel, J. Am. Chem. Soc. 1992, 114, 5729-5733. b) J. H. Williams, Acc. Chem. Res. 1993, 26, 593-598. c) F. Cozzi, F. Ponzini, R. Annunziata, M. Cinquini, J. S. Siegel, Angew. Chem. 1995, 107, 1092-1094; Angew. Chem. Int. Ed. Engl. 1995, 34, 1019-1020. d) S. K. Burtley, G. A. Petsko, Science, 1985, 229, 23-29.

[7] a) V. P. Santarelli, A. L. Eastwood, D. A. Dougherty, R. Horn, C. A. Ahern, J. Biol. Chem. 2007, 282, 80448051. b) H. Ihm, S. Yun, H. G. Kim, J. K. Kim, K. S. Kim, Org. Lett. 2002, 4, 2897-2900. c) H. Adams, C. A. Hunter, K. R. Lawson, J. Perkins, S. E. Spey, C. J. Urch, J. M. Sanderson, Chem. Eur. J. 2001, 7, 4863-4877. d) P. Lakshminarasimhan, R. B. Sunoj, J. Chandrasekhar, V. Ramamurthy, J. Am. Chem. Soc. 2000, 122, 48154816. e) D. A. Dougherty, Acc. Chem. Res. 2013, 46, 885-893.

[8] a) M. Mascal, A. Armstrong, M. D. Bartberger, J. Am. Chem. Soc. 2002, 124, 6274-6276. b) I. Alkorta, I. Rozas, J. Elguero, J. Am. Chem. Soc. 2002, 124, 8593-8598. c) H. T. Chifotides, K. R. Dunbar, Acc. Chem. Res. 2013, 46, 894-906. d) P. Gamez, T. J. Mooibroek, S. J. Teat, J. Reedijk, Acc. Chem. Res. 2007, 40, 435-444. e) D.-X. Wang, M.-X. Wang, J. Am. Chem. Soc. 2012, 135, 892-897. f) B. P. Hay, V. S. Bryantsev, Chem. Commun. 2008, 2417-2428. g) O. B. Berryman, D. W. Johnson, Chem. Commun. 2009, 3143-3153. h) A. Frontera, P. Gamez, M. Mascal, T. J. Mooibroek, J. Reedijk, Angew. Chem. Int. Ed. 2011, 50, 9564-9583; Angew. Chem. 2011, 123, 9736-9756. i) P. Ballester, Acc. Chem. Res. 2012, 46, 874-884. j) S. Matile, A. Vargas Jentzsch, J. Montenegro, A. Fin, Chem, Soc. Rev. 2011, 40, 2453-2474. k) Y. Zhao, C. Beuchat, Y. Domoto, J. Gajewy, A. Wilson, J. Mareda, N. Sakai, S. Matile, J. Am. Chem. Soc. 2014, 136, 2101-2111. 1) A. Vargas Jentzsch, A. Hennig, J. Mareda, S. Matile, Acc. Chem Res. 2013, 46, 2791-2800. m) S. E. Wheeler, J. W. G. Bloom, Chem. Commun. 2014, 50, 11118-11121.

[9] a) M. Nishio, Y. Umezawa, K. Honda, S. Tsuboyama, H. Suezawa, CrystEngComm 2009, 11, 1757-1788. b) M. Hirota, K. Sakaibara, H. Suezawa, T. Yuzuri, E. Ankai, M. Nishio, J. Phys. Org. Chem. 2000, 13, 620-623.

[10] a) L. Yang, C. Adam, G. S. Nichol, S. L. Cockroft, Nat. Chem. 2013, 5, 1006-1010. b) A. Nijamudheen, D. Jose, A. Shine, A. Datta, J. Phys. Chem. Lett. 2012, 3, 1493-1496. c) A. E. Aliev, Z. A. Mia, H. S. Khaneja, F. D. King, J. Phys. Chem. A 2012, 116, 1093-1109. d) C. A. Hunter, Angew. Chem. Int. Ed. Engl. 2004, 43, 5310-5324. e) A. Heßelmann, F. Ferraro, J. Mol. Model. 2019, 25, 69.

[11] a) B. Lutz, J. A. Kanters, J. van der Maas, J. Kroon, T. Steiner, J. Mol. Struct. 1998, 440, 81-87. b) M. A. Viswamitra, R. Radhakrishnan, J. Bandekar, G. R. Desiraju, J. Am. Chem. Soc. 1993, 115, 4868-4869. c) H. S. Rzepa, M. H. Smith, M. L. Webb, J. Chem. Soc. Perkin Trans. 2 1994, 703-707. d) M. Parvez, Acta Crystallogr. Sect. C: Cryst. Struct. Commun. 1987, 43, 1408-1410. e) H. E. Zimmerman, M. J. Zuraw, J. Am. Chem. Soc. 1989, 111, 7974-7989.

[12] a) K. C. Janda, C. Hemminger, J. S. Winn, S. E. Novick, S. J. Harris, W. Klemperer, J. Chem. Phys. 1975, 63, 1419-1421. b) J. M. Steed, T. A. Dixon, W. Klemperer, J. Chem. Phys. 1979, 70, 4940-4946.

[13] M. Nakamura, M. Ōki, H. Nakanishi, O. Yamamoto, Bull. Chem. Soc. Jpn. 1974, 47, 2415-2419.

[14] a) S. Paliwal, S. Geib, C. S. Wilcox, J. Am. Chem. Soc. 1994, 116, 4497-4498. b) E. Kim, S. Paliwal, C. S. Wilcox, J. Am. Chem. Soc. 1998, 120, 11192-11193.

[15] a) F. Hof, D. M. Scofield, W. B. Schweizer, F. Diederich, Angew. Chem. 2004, 116, 5166-5169; Angew. Chem. Int. Ed. 2004, 43, 5056-5059. b) S. L. Cockroft, C. A. Hunter, Chem. Commun. 2006, 3806-3808. c) S. L. 
Cockroft, C. A. Hunter, Chem. Commun. 2009, 3961-3963. d) B. Bhayana, M. R. Ams, J. Org. Chem. 2011, 76, 3594-3596. e) B. Bhayana, J. Org. Chem. 2013, 78, 6758-6762. f) B. Bhayana, D. S. Dickie, Cryst. Growth Des. 2018, 18, 6404-6410.

[16] a) I. K. Mati, S. L. Cockroft, Chem. Soc. Rev. 2010, 39, 4195-4205. b) M. A. Strauss, H. A. Wegner, Eur. J. Org. Chem. 2019, 295-302. c) J. Hwang, P. Li, K. D. Shimizu, Org. Biomol. Chem. 2017, 15, 1554-1564.

[17] a) T. V. Nguyen, D. J. Sinclair, A. C. Willis, M. S. Sherburn, Chem. Eur. J., 2009, 15, 5892-5895. b) J. M. Maier, P. Li, E. C. Vik, C. J. Yehl, S. M. Strickland, K. D. Shimizu, J. Am. Chem. Soc. 2017, 139, 6550-6553. c) S. Rosel, J. Becker, W. D. Allen, P. R. Schreiner, J. Am. Chem. Soc. 2018, 140, 14421-14432.

[18] a) S. E. Wheeler, T. J. Seguin, Y. Guan, A. C. Doney, Acc. Chem. Res. 2016, 49, 1061-1069. b) K. E. Riley, P. Hobza, WIREs Comput. Mol. Sci. 2011, 1, 3-17. c) P. L. A. Popelier, Curr. Top. Med. Chem. 2012, 12, 19241934. d) B. C. B. Symons, D. J. Williamson, C. M. Brooks, A. L. Wilson, P. L. A. Popelier, ChemistryOpen 2019, 8, 1-12. e) C. D. Sherrill, Acc. Chem. Res. 2013, 46, 1020-1028. f) T. M. Parker, L. A. Burns, R. M. Parrish, A. G. Ryno, C. D. Sherrill, J. Chem. Phys. 2014, 140, 094106.

[19] a) M. F. Schlecht, Molecular Modeling on the PC. Wiley-VCH, New York, 1998. b) PCMODEL, version 8.5, Serena Software, Gilbert, K.E., Bloomington. c) Gaussian 09, Revision D.01, M. J. Frisch, G. W. Trucks, H. B. Schlegel, G. E. Scuseria, M. A. Robb, J. R. Cheeseman, G. Scalmani, V. Barone, G. A. Petersson, H. Nakatsuji, X. Li, M. Caricato, A. Marenich, J. Bloino, B. G. Janesko, R. Gomperts, B. Mennucci, H. P. Hratchian, J. V. Ortiz, A. F. Izmaylov, J. L. Sonnenberg, D. Williams-Young, F. Ding, F. Lipparini, F. Egidi, J. Goings, B. Peng, A. Petrone, T. Henderson, D. Ranasinghe, V. G. Zakrzewski, J. Gao, N. Rega, G. Zheng, W. Liang, M. Hada, M. Ehara, K. Toyota, R. Fukuda, J. Hasegawa, M. Ishida, T. Nakajima, Y. Honda, O. Kitao, H. Nakai, T. Vreven, K. Throssell, J. A. Montgomery, Jr., J. E. Peralta, F. Ogliaro, M. Bearpark, J. J. Heyd, E. Brothers, K. N. Kudin, V. N. Staroverov, T. Keith, R. Kobayashi, J. Normand, K. Raghavachari, A. Rendell, J. C. Burant, S. S. Iyengar, J. Tomasi, M. Cossi, J. M. Millam, M. Klene, C. Adamo, R. Cammi, J. W. Ochterski, R. L. Martin, K. Morokuma, O. Farkas, J. B. Foresman, D. J. Fox, Gaussian, Inc., Wallingford CT, 2013. d) Y. Zhao, D. G. Truhlar, Chem. Phys. Lett. 2011, 502, 1-13. e) M. Cossi, N. Rega, G. Scalmani, V. Barone, J. Comp. Chem. 2003, 24, 669-681.

[20] a) F. Cozzi, M. Cinquini, R. Annunziata, J. S. Siegel, J. Am. Chem. Soc. 1993, 115, 5330-5331. b) F. Cozzi, J. S. Siegel, Pure \& Appl. Chem. 1995, 67, 683-689. c) F. Cozzi, R. Annunziata, M. Benaglia, M. Cinquini, L. Raimondi, K. K. Baldridge, J. S. Siegel, Org. Biomol. Chem. 2003, 1, 157-162.

[21] a) J. A. Zoltewicz, N. M. Maier, W. M. F. Fabian, J. Org. Chem. 1996, 61, 7018-7021. b) J. A. Zoltewicz, N. M. Maier, W. M. F. Fabian, J. Org. Chem. 1997, 62, 2763-2766.

[22] L. Raimondi, M. Benaglia, F. Cozzi, Eur. J. Org. Chem. 2014, 4993-4998.

[23] S. M. Verma, N. B. Singh, Aust. J. Chem. 1976, 29, 295-300

[24] a) B. U. Emenike, S. N. Bey, B. C. Bigelow, S. V. S. Chakravartula, Chem. Sci. 2016, 7, 1401-1407. b) B. U. Emenike, S. N. Bey, R. A. Spinelle, J. T. Jones, B. Yoo, M. Zeller, Phys. Chem. Chem. Phys. 2016, 18, 30940-30945. c) B. U. Emenike, R. A. Spinelle, A. Rosario, D. W. Shinn, B. Yoo, J. Phys. Chem. A 2018, 122, 909-915.

[25] a) P. Li, C. Zhao, M. D. Smith, K. D. Shimizu, J. Org. Chem. 2013, 78, 5303-5313. b) C. Zhao, R. M. Parrish, M. D. Smith, P. J. Pellechia, C. D. Sherrill, K. D. Shimizu, J. Am. Chem. Soc. 2012, 134, 14306-14309. c) W. R. Carroll, C. Zhao, M. D. Smith, P. J. Pellechia, K. D. Shimizu, Org. Lett. 2011, 13, 4320-4323. d) P. Li, J. Hwang, J. M. Maier, C. Zhao, V. Kaborda, M. D. Smith, P. J. Pellechia, K. D. Shimizu, Cryst. Growth Des. 2015, 15, 
3561-3564. e) W. R. Carroll, P. Pellechia, K. D. Shimizu, Org. Lett. 2008, 10, 3547-3550. f) P. Li, J. M. Maier, E. C. Vik, C. J. Yehl, B. E. Dial, A. E. Rickher, M. D. Smith, P. J. Pellechia, K. D. Shimizu, Angew. Chem. Int. Ed. 2017, 56, 7209-7212. g) J. M. Maier, P. Li, J. Hwang, M. D. Smith, K. D. Shimizu, J. Am. Chem. Soc. 2015, 137, 8014-8017. h) J. Hwang, P. Li, M. D. Smith, K. D. Shimizu, Angew. Chem. Int. Ed. 2016, 55, 8086-8089. i) Y. S. Chong, W. R. Carroll, W. G. Burns, M. D. Smith, K. D. Shimizu, Chem. Eur. J. 2009, 15, 9117-9126. j) J. Hwang, E. C. Vik, I. Karki, K. D. Shimizu, Org. Chem. Front. 2019, 6, 1266-1271.

[26] a) W. B. Motherwell, J. Moïse, A. E. Aliev, M. Nič, S. J. Coles, P. N. Horton, M. B. Hursthouse, G. Chessari, C. A. Hunter, J. G. Vinter, Angew. Chem. Int. Ed. 2007, 46, 7823-7826; Angew. Chem. 2007, 119, 7969-7972. b) A. E. Aliev, J. Moise, W. B. Motherwell, M. Nič, D. Courtier-Murias, D. A. Tocher, Phys. Chem. Chem. Phys. 2009, 11, 97-100. c) A. E. Aliev, J. R. T. Arendorf, I. Pavlakos, R. B. Moreno, M. J. Porter, H. S. Rzepa, W. B. Motherwell, Angew. Chem. Int. Ed. 2015, 54, 551-555; Angew. Chem. 2015, 127, 561-565. d) I. Pavlakos, T. Arif, A. E. Aliev, W. B. Motherwell, G. J. Tizzard, S. J. Coles, Angew. Chem. Int. Ed. 2015, 54, 8169-8174; Angew. Chem. 2015, 127, 8287-8292. (e) W. B. Motherwell, R. B. Moreno, I. Pavlakos, J. R. T. Arendorf, T. Arif, G. J. Tizzard, S. J. Coles, A. E. Aliev, Angew. Chem. Int. Ed. 2018, 57, 1193-1198; Angew. Chem. 2018, $130,1207-1212$.

[27] J. Hwang, P. Li, M. D. Smith, C. E. Warden, D. A. Sirianni, E. C. Vik, J. M. Maier, C. J. Yehl, C. D. Sherrill, K. D. Shimizu, J. Am. Chem. Soc. 2018, 140, 13301-13307.

[28] (a) M. Ōki, Acc. Chem. Res. 1990, 23, 351-356. (b) M. Ōki, M. Nishino, K. Kaieda, T. Nakashima, S. Toyota, S. Bull. Chem. Soc. Jpn. 2001, 74, 357-361.

[29] a) B. W. Gung, X. Xue and H. J. Reich, J. Org. Chem. 2005, 70, 3641-3644. b) B. W. Gung, X. Xue, H. J. Reich, J. Org. Chem. 2005, 70, 7232-7237. c) B. W. Gung, M. Patel, X. Xue, J. Org. Chem. 2005, 70, 10532-10537. d) B. W. Gung, Y. Zou, Z. Xu, J. C. Amicangelo, D. G. Irwin, S. Ma, H.-C. Zhou, J. Org. Chem. 2008, 73, 689693.

[30] a) W. B. Jennings, B. M. Farrell, J. F. Malone, J. Org. Chem. 2006, 71, 2277-2282. b) W. B. Jennings, N. J. P. McCarthy, P. Kelly, J. F. Malone, J. F. Org. Biomol. Chem. 2009, 7, 5156-5162. c) W. B. Jennings, N. O'Connell, J. F. Malone, D. R. Boyd, D. R. Org. Biomol. Chem. 2013, 11, 5278-5291. d) M. E. González-Rosende, E. Castillo, W. B. Jennings, J. F. Malone, Org. Biomol. Chem. 2017, 15, 1484-1494.

[31] a) K. B. Muchowska, C. Adam, I. K. Mati, S. L. Cockroft, J. Amer. Chem. Soc. 2013, 135, 9976-9979. b) I. K. Mati, C. Adam, S. L. Cockroft, Chem. Sci. 2013, 4, 3965-3972.

[32] a) M. P. Hinderaker, R. T. Raines, Protein Sci. 2003, 12, 1188-1194. b) J. A. Hodges, R. T. Raines, Org. Lett. 2006, 8, 4695-4697. c) A. Choudhary, D. Gandla, G. R. Krow, R. T. Raines, J. Am. Chem. Soc. 2009, 131, 72447246. d) R. W. Newberry, B. VanVeller, I. A. Guzei, R. T. Raines, J. Am. Chem. Soc. 2013, 135, 7843-7846. e) R. W. Newberry, G. J. Bartlett, B. VanVeller, D. N. Woolfson, R. T. Raines, Protein Sci. 2014, 23, 284-288. f) A. Choudhary, R. W. Newberry, R. T. Raines, Org. Lett. 2014, 16, 3421-3423. g) R. W. Newberry, R. T. Raines, ACS Chem. Biol. 2014, 9, 880-883. h) A. Choudhary, R. W. Newberry, R. T. Raines, Org. Lett. 2014, 16, 34213423. i) R. W. Newberry, S. J. Orke, R. T. Raines, Org. Lett. 2016, 16, 3614-3417. j) R. W. Newberry, R. T. Raines, Acc. Chem. Res. 2017, 50, 1838-1846. k) H. R. Kilgore, R. T. Raines, J. Am. Chem. Soc. 2018, 140, 17606-17611. 1) I. W. Windsor, B. Gold, R. T. Raines, ACS Catal. 2019, 9, 1464-1471.

[33] a) W. B. Motherwell, C. E. Atkinson, A. E. Aliev, S. Y. Wong, B. H. Warrington, Angew. Chem. Int. Ed. 2004, 43, 1225-1228. b) C. E. Atkinson, A. E. Aliev, W. B. Motherwell, Chem. Eur. J. 2003, 9, 1714-1723. 
[34] a) Y. Fukazawa, T. Fujihara, S. Usui, Tetrahedron Lett. 1986, 27, 5621-5624. b) Y. Fukazawa, T. Okajima, T. Fujihara, S. Usui, Tetrahedron Lett. 1986, 29, 5961-5964. c) Y. Fukazawa, T. Fujihara, S. Usui, Tetrahedron Lett. 1989, 30, 3163-3166.

[35] B. T. G. Lutz, J. H. van der Maas, J. Mol. Struct. 1997, 436-437, 213-231.

[36] A. Bondi, J. Phys. Chem. 1964, 68, 441-451.

[37] a) M. Swart, J. G. Snijders, P. T. van Duijnen, J. Comput. Methods Sci. Eng. 2004, 4, 419-425. b) P. Schwerdtfeger, in Atoms, Molecules and Clusters in Electric Fields (Ed.: G. Maroulis), Imperial College Press, London, 2006, pp. 10-15.

[38] a) E. R. Johnson, S. Keinan, P. Mori-Sanchez, J. Contreras-Garcia, A. J. Cohen, W. Yang, J. Am. Chem. Soc. 2010, 132, 6498-6506. b) J. R. Lane, J. Contreras-García, J.-P. Piquemal, B. J. Miller, H. G. Kjaergaard, J. Chem. Theory Comput. 2013, 9, 3263-3266.

[39] S. Yamada, N. Yamamoto, E. Takamori, Org. Lett. 2015, 17, 4862-4865.

[40] J. Luccarelli, I. M. Jones, S. Thomson, A. D. Hamilton, Org. Biomol. Chem. 2017, 15, 9156-9163.

[41] A. Lypson, C. S. Wilcox, J. Org. Chem. 2017, 82, 898-909.

[42] P. Cornago, R. M. Claramunt, L. Bouissane, J. Elguero, Tetrahedron 2008, 64, 3667-3673.

[43] a) J. C. Morales, E. T. Kool, Nat. Struct. Biol. 1998, 5, 950-954. b) K. M. Guckian, R. X. F. Ren, N. C. Chaudhuri, D. C. Tahmassebi, E. T. Kool, J. Am. Chem. Soc. 2000, 122, 2213-2227. c) E. T. Kool, Annu. Rev. Biophys. Biomol. Struct. 2001, 30, 1-22. d) F. Wojciechowski, C. J. Leumann, Chem. Soc. Rev. 2011, 40, 5669-5679.

[44] a) M. A. Blanco, A. Martín Pendás, E. Francisco, J. Chem. Theory Comput. 2005, 1, 1096-1109. b) J. C. R. Thacker, P. L. A. Popelier, J. Phys. Chem. A 2018, 122, 1439-1450. c) P. L. A. Popelier, P. I. Maxwell, J. C. R. Thacker, I. Alkorta, Theor. Chem. Acc. 2019, 138, 12. d) J. C. R. Thacker, P. L. A. Popelier, Theor. Chem. Acc. 2017, 136, 86. e) J. C. R. Thacker, M. A. Vincent, P. L. A. Popelier, Chem. Eur. J. 2018, 14, 11200-11210.

[45] M. O. Sinnokrot, C. D. Sherrill, J. Phys. Chem. A 2006, 110, 10656-10668. 